NBER WORKING PAPER SERIES

\title{
UNINTENDED CONSEQUENCES OF TRANSPORTATION CARBON POLICIES: LAND-USE, EMISSIONS, AND INNOVATION
}

\author{
Stephen P. Holland \\ Jonathan E. Hughes \\ Christopher R. Knittel \\ Nathan C. Parker \\ Working Paper 19636 \\ http://www.nber.org/papers/w19636 \\ NATIONAL BUREAU OF ECONOMIC RESEARCH \\ 1050 Massachusetts Avenue \\ Cambridge, MA 02138 \\ November 2013
}

The authors thank Soren Anderson, Severin Borenstein, Meghan Busse, Garth Heutel, Mark Jacobsen, Randall Walsh, Catherine Wolfram and seminar participants at the Heartland Environmental and Resource Economics Conference, Iowa State University, the NBER Environmental and Energy Economics spring meeting, the University of California Energy Institute, the University of North Carolina at Greensboro, the University of Texas, the Colorado School of Mines and the Massachusetts Institute of Technology for helpful comments. Knittel gratefully acknowledges support from the Institute of Transportation Studies at UC Davis. A portion of the paper was written while Knittel was a visitor at the Energy Institute at Haas. The views expressed herein are those of the authors and do not necessarily reflect the views of the National Bureau of Economic Research.

At least one co-author has disclosed a financial relationship of potential relevance for this research. Further information is available online at http://www.nber.org/papers/w19636.ack

NBER working papers are circulated for discussion and comment purposes. They have not been peerreviewed or been subject to the review by the NBER Board of Directors that accompanies official NBER publications.

(C) 2013 by Stephen P. Holland, Jonathan E. Hughes, Christopher R. Knittel, and Nathan C. Parker. All rights reserved. Short sections of text, not to exceed two paragraphs, may be quoted without explicit permission provided that full credit, including $@$ notice, is given to the source. 
Unintended Consequences of Transportation Carbon Policies: Land-Use, Emissions, and Innovation Stephen P. Holland, Jonathan E. Hughes, Christopher R. Knittel, and Nathan C. Parker NBER Working Paper No. 19636

November 2013

JEL No. H4,Q2,Q4,Q5

\begin{abstract}
$\underline{\text { ABSTRACT }}$
Renewable fuel standards, low carbon fuel standards, and ethanol subsidies are popular policies to incentivize ethanol production and reduce emissions from transportation. Compared to carbon trading, these policies lead to large shifts in agricultural activity and unexpected social costs. We simulate the 2022 Federal Renewable Fuel Standard (RFS) and find that energy crop production increases by 39 million acres. Land- use costs from erosion and habitat loss are between \$277 and \$693 million. A low carbon fuel standard (LCFS) and ethanol subsidies have similar effects while costs under an equivalent cap and trade (CAT) system are essentially zero. In addition, the alternatives to CAT magnify errors in assigning emissions rates to fuels and can over or under-incentivize innovation. These results highlight the potential negative efficiency effects of the RFS, LCFS and subsidies, effects that would be less severe under a CAT policy.
\end{abstract}

Stephen P. Holland

Bryan School of Business and Economics University of North Carolina, Greensboro

P.O. Box 26165

Greensboro, NC 27402-6165

and NBER

sphollan@uncg.edu

Jonathan E. Hughes

Department of Economics

University of Colorado at Boulder

0256 UCB

Boulder, CO 80309

jonathan.e.hughes@colorado.edu
Christopher R. Knittel

MIT Sloan School of Management

100 Main Street, E62-513

Cambridge, MA 02142

and NBER

knittel@mit.edu

Nathan C. Parker

Institute of Transportation Studies

University of California, Davis

ncparker@ucdavis.edu 


\section{Introduction}

Policy makers have pursued a variety of policies to lower carbon emissions from transportation fuels. A number of studies have shown that renewable fuel standards (RFS) or mandates, low carbon fuel standards (LCFS) and direct subsidies are inefficient instruments for achieving emissions reductions relative to cap and trade (CAT) or carbon pricing (Cui et al., 2011; de Gorter and Just, 2010; Holland, Hughes, and Knittel, 2009, Holland et al., 2013; Lapan and Moschini, 2012; Khanna, Ando, and Taheripour, 2008, Chen et al., 2011). Despite these well-documented inefficiencies, the inefficient policies persist and there is little political support to replace them with more efficient policies.1 Unfortunately, these inefficient policies can also have unintended consequences. For example, a policy which leads to more agricultural production from intensive cultivation will lead to more erosion and habitat loss than a policy which leads to an equivalent carbon reduction but less intensive agricultural production. We ask whether unintended consequences associated with ethanol blending, land-use changes, uncontrolled emissions, and innovation incentives increase or decrease the relative inefficiencies of the different policies. Our results highlight the potential negative effects of current transportation sector carbon policies, effects that would be less severe under a CAT policy.

To assess these unintended consequences, we simulate long-run equilibrium outcomes for two existing policies: ethanol subsidies and the 2022 US RFS; and for two policies currently under consideration: a national LCFS and a CAT system. To increase comparability across the policies, we calibrate the LCFS and CAT to achieve the same reduction in carbon emissions as the RFS. Our simulations exploit engineering models of ethanol production and detailed data on agricultural production and waste biomass resources to construct countylevel supply curves for corn ethanol and six cellulosic ethanol fuels. Based on these supply curves, we estimate emissions, ethanol production, energy crop and biomass consumption, land-use, and related externalities under each policy.

We find that, as intended, carbon emissions fall under each of the policies: by 10.2 percent for the RFS (and LCFS and CAT) and by 6.9 percent for the subsidies. However, these emissions reductions are achieved by dramatically different processes. In particular, annual ethanol production increases substantially under the RFS, LCFS, and subsidies by 14.9 to 18.5 billion gasoline gallon equivalents (gge), relative to our business as usual scenario. Under CAT, the increase is much more modest at approximately 3.8 billion gge.

\footnotetext{
${ }_{1}^{1}$ Holland et al. (2013) provide evidence that the skewed gains from the inefficient policies may partially explain to popularity of inefficient policies.
} 
The inefficient policies, by requiring substantially more ethanol production, have several unintended consequences. First, the existing vehicle fleet may not be able to use the vast amounts of ethanol required under these policies. The existing vehicle fleet can safely utilize approximately a 10 percent ethanol blend by volume (the "blend wall") $\left.\right|^{2}$ We estimate that the inefficient policies would require substantially more ethanol than can currently be blended, whereas CAT would not.

Second, because some ethanol is produced from energy crops, the policies would require shifts in agricultural activity. We estimate that under the RFS, LCFS and subsidies, between 27.6 and 39.0 million additional acres of land are used for energy crop production, or between 6 and 9 percent of existing US crop land. Under CAT, only 1.2 million additional acres are required. These large shifts in agricultural activity create social costs from habitat loss and increased erosion. We estimate land-use related costs between $\$ 147$ million and $\$ 693$ million for the RFS, LCFS, and subsidies. Under CAT, these costs are essentially zero.

A third unintended consequence arises due to the impossibility of precisely measuring lifecycle carbon emissions from biofuels. This implies that regulated emissions intensities may reflect political considerations as well as imprecise scientific estimates. Thus, large increases in ethanol production can lead to "uncontrolled" emissions above or below the level intended by policy makers. Because the alternatives to CAT require more ethanol production, these policies are much more sensitive to errors in assigning emissions intensities. If the emissions rate for corn ethanol is 10 percentage points higher than expected, we estimate between $\$ 174$ million and $\$ 308$ in damages from uncontrolled emissions under the RFS, LCFS or subsidies. Under CAT, damages from uncontrolled emissions are only $\$ 30$ million.

Finally, because cellulosic or "second-generation" ethanol fuels cannot yet be produced at commercial scale, the innovation incentives of any carbon policy are crucial. We analyze the incentives for developing cellulosic ethanol, reducing its costs, and lowering fuel emission intensities across the different policies. We first estimate the social gains from innovation across the policies. Under CAT, we find that social gains from innovation are positive and substantial. However, the social gains under the inefficient policies are surprising. Social gains depend on both the amount each policy relies on ethanol and on whether increased ethanol use increases or decreased the inefficiency of the policy. Surprisingly, in some cases, this latter effect can dominate. In fact, we estimate that social gains from innovation can be negative for the inefficient policies.

\footnotetext{
${ }^{2}$ While the US EPA has enacted partial waivers to allow recent production automobiles to operate on ethanol blends as high as 15 percent, automakers have challenged these decisions citing possible engine damage.
} 
We also investigate the distribution of gains from innovation across consumers and the different types of firms under the policies. Private incentives for innovation can be too large or too small depending on whether surplus gains to ethanol producers are larger or smaller than social gains. We find that under CAT, incentives for innovation are generally too small when ignoring carbon market revenue because some gains accrue to consumers. However, we estimate that carbon market revenue would be sufficient to compensate producers fully for efficient innovation expenditures. Under the inefficient policies, the gains to ethanol producers can lead to very inefficient incentives. For example, under subsidies, we estimate that gains to producers are substantially greater than social gains. Under the RFS and LCFS, private incentives for innovation can be too large, too small or negative. Under the LCFS and CAT, corn producers are harmed by innovation that leads to the development of cellulosic ethanol, lowers cellulosic costs or reduces cellulosic emissions. In general, the different types of innovation lower energy prices, increase consumer surplus, and reduce carbon abatement costs.

Our work contributes to a large literature on the agricultural and land use impacts of US carbon and biofuel policies. Recent studies focus primarily on the US RFS and combinations of the RFS with ethanol subsidies or carbon taxes (Bento, Klotz, and Landry, 2012; Chakravorty et al., 2013; Keeney and Hertel, 2009; Chen et al., 2011). Consistent with our results, these studies find large increases in corn and total agricultural acreage under the RFS. Shifts in farming can lead to large food price effects, on the order of 17 to 20 percent (Chakravorty et al. 2013; Roberts and Schlenker, 2013) $!^{3}$ A major contribution of our work is to contrast these effects across the RFS and alternate policies that achieve the same environmental goal. In addition, we estimate non-carbon costs related to land-use changes across policies.

A second literature estimates indirect land use effects of US biofuel policies. Dumortier et al. (2011) and Keeney and Hertel (2009) show that the magnitudes of these effects are highly uncertain and depend on modelers' assumptions about yields, trade responses and the availability of idle cropland. Our analysis of uncontrolled emissions suggests carbon policies which rely more heavily on ethanol production magnify the effects of these uncertainties.

Finally, while a large theoretical literate has explored incentives for innovation, few studies have quantified gains from innovation across different policies $4^{4}$ We estimate these effects

\footnotetext{
$\sqrt[3]{\text { Zilberman et al. }}(2013)$ provide a recent review of estimates of the effect of biofuel mandates on food prices.

${ }^{4}$ Examples of the later include Johnstone, Haščič, and Popp 2010) who study patent applications under various policies and Jaffe and Stavins (1995) who study the effect of taxes, standards and subsidies on the adoption of energy efficient building technologies.
} 
for CAT, the LCFS and ethanol subsidies. Much of the literature has focused on abatement costs (Milliman and Prince, 1989; Jung, Krutilla, and Boyd, 1996; Fischer, Parry, and Pizer, 2003). We also consider effects in the output market and estimate both the total gains from innovation and the private gains to producers $5^{5}$ This distinction is important as the private gains to cellulosic ethanol producers under the LCFS and subsidies are much larger than the social benefits from innovation.

Overall, we show that transportation sector carbon policies vary along a number of important dimensions. The alternatives to CAT create different fuel mixes, land use patterns, and incentives for innovation. These differences can increase social costs substantially. This highlights the important trade-offs faced by policy makers in evaluating approaches for reducing carbon emissions in transportation.

\section{Biofuel policies}

We begin by illustrating the incentives created by each biofuel policy. We consider four alternatives, renewable fuel standards (RFS), low carbon fuel standards (LCFS), a carbon cap and trade system (CAT), and ethanol subsidies (SUBS). Our modeling approach is similar to Holland, Hughes, and Knittel (2009) and Holland et al. (2013). A single, representative, price taking firm produces quantities $q_{1}, q_{2} \ldots q_{n-1}$ of different ethanol fuels and $q_{n}$ gallons of gasoline ${ }^{6}$ Let $m c_{i}\left(q_{i}\right)$ be the marginal cost of producing fuel $i$ with $m c_{i}^{\prime}\left(q_{i}\right) \geq 0$ and with carbon emissions rate $\beta_{i}$. We assume the fuels are perfect substitutes, once adjusted for volumetric energy content, such that all fuel trades at a common price $p$. The firm maximizes profit subject to the constraints or incentives created by each policy.

Carbon emissions rates of biofuels are notoriously difficult to measure. Emissions must be determined on a life-cycle basis, which requires calculating a number of difficult parameters such as indirect land use effects. Nonetheless, for a carbon policy, regulators must determine how much carbon is emitted from each fuel. This determination, which may be based on politics as much as science, will determine the resulting equilibrium under each policy. The

\footnotetext{
5 Milliman and Prince $(1989)$ and Jung, Krutilla, and Boyd $(1996)$, argue that market based mechanisms provide greater incentives for innovation compared to command and control policies. Emissions taxes and auctioned permits provide greater incentives than free permits when innovators appropriate a fixed fraction of gains. However, in a competitive setting Fischer, Parry, and Pizer (2003) show that the relative welfare ranking of market based instruments depends on innovation spillovers, costs and environmental benefits. Allowing for imperfect competition in permit and output markets, Montero (2002) shows that incentives for innovation can be greater under standards than under market based policies.

${ }^{6}$ Our simulations adjust for differences in the energy content of fuels. All quantities are expressed in units of gasoline gallon equivalents (gge).
} 
$\beta_{i}$ 's in this section are the "regulated" carbon emissions rates rather than the "true" carbon emissions rates. Ideally, the regulated and true carbon emissions rates would be the same. Our analysis of uncontrolled emissions studies differences between the regulated and true carbon emissions rates.

\subsection{Renewable fuel standard}

The US Renewable Fuel Standard (RFS) was first created under the Energy Policy Act of 2005. It was subsequently updated under the Energy Independence and Security Act of 2007 (U.S. Congress, 2007). The RFS sets volumetric targets for ethanol production in three categories, cellulosic (cell), advanced (adv) and total (tot) renewable fuels. The categories roughly capture the carbon emissions of each fuel type (e.g., $\beta_{c e l l}<\beta_{a d v}<\beta_{t o t}$ ) but do not differentiate within category. The categories are additive such that cellulosic production counts towards both the advanced and total renewable fuel requirements and advanced renewable fuels count towards the total requirement. In 2022, the RFS requires 36 billion gallons (24 billion gge) per year of renewable fuel including 21 billion and 16 billion gallons of advanced and cellulosic fuels.

The RFS is implemented using ratios that translate the volumetric targets into proportional targets based on projected gasoline demand. Specifically, the RFS ratio $\sigma_{R F S j}=\frac{q_{j}}{q_{n}}$ requires $\sigma_{R F S}$ gallons of ethanol of type $j$ for every gallon of gasoline produced. To allow ethanol production by the least cost firms, tradable Renewable Identification Numbers (RINs) are created by producing each type of ethanol and are used by firms to demonstrate compliance. Because firms can sell RINs, they act as a subsidy to ethanol production. The first-order conditions for ethanol are:

$$
p=m c_{j}\left(q_{j}\right)-p_{R I N j}
$$

where, $p_{R I N j}$ is the price of a RIN of type $j$ with $j \in\{$ cell, adv, tot $\}$. The RFS also acts as an implicit tax on gasoline because producing additional gasoline increases the ethanol (RIN) procurement obligation. The first-order condition for gasoline production is:

$$
p=m c_{n}\left(q_{n}\right)+p_{R I N c e l l} \sigma_{c e l l}+p_{R I N a d v}\left(\sigma_{a d v}-\sigma_{c e l l}\right)+p_{R I N t o t}\left(\sigma_{t o t}-\sigma_{a d v}\right)
$$

where the $\sigma$ terms reflect the fact that additional gasoline production raises the ethanol procurement obligation and that the three ethanol categories are additive. For example, an additional gallon of gasoline requires $\sigma_{\text {cell }}$ additional gges of cellulosic ethanol or cellu- 
losic RINs which costs $p_{R I N c e l l} \sigma_{c e l l}$. For advanced ethanol, cellulosic fuel is counted toward the obligation such that the additional cost for advanced ethanol is $p_{R I N a d v}\left(\sigma_{a d v}-\sigma_{c e l l}\right)$. Similarly for the total requirement, the additional cost taking into account advanced fuel is $p_{\text {RINtot }}\left(\sigma_{\text {tot }}-\sigma_{\text {adv }}\right)$. For more details see Holland et al. (2013).

\subsection{Low carbon fuel standard}

Low carbon fuel standards (LCFSs) set average carbon intensity requirements for transportation fuels. This approach has been influential at both the state and federal levels. In 2009, California adopted an LCFS requiring the state reduce the average carbon intensity of transportation fuel 10 percent by 2020 (State of California, 2010). Oregon has adopted a policy similar to the California LCFS.7 Washington and two consortia of Midwest, Northeast and mid-Atlantic states have also considered implementing LCFSs. 8 At the federal level, lawmakers have considered adoption of a national LCFS based on the California policy. Most recently, early versions of the Waxman-Markey cap and trade bill included provisions for a national LCFS.9

Under an LCFS, a firm's quantity weighted average emissions intensity for transportation fuel may not exceed the standard $\sigma_{L C F S}$. Using the notation above, the LCFS constraint is:

$$
\frac{\beta_{1} q_{1}+\beta_{2} q_{2}+\cdots+\beta_{n} q_{n}}{q_{1}+q_{2}+\cdots+q_{n}} \leq \sigma_{L C F S}
$$

Firms adjust total fuel output and the relative quantities of fuel produced to comply with the regulation. The first-order condition for fuel $i$ is:

$$
p=m c_{i}\left(q_{i}\right)+\lambda_{L C F S}\left(\beta_{i}-\sigma_{L C F S}\right)
$$

where $\lambda_{L C F S}$ is the shadow value of the LCFS constraint. Notice that for high carbon fuels, $\beta_{i}>\sigma_{L C F S}$, the last term in equation 4 is positive and the policy acts like an implicit tax on production. For low carbon fuels, $\beta_{i}<\sigma_{L C F S}$, the policy acts like an implicit subsidy.

\footnotetext{
${ }^{7}$ See http://www.deq.state.or.us/aq/committees/docs/lcfs/reportFinal.pdf

${ }^{8}$ See http://www.ecy.wa.gov/climatechange/fuelstandards.htm, http://www.midwesterngovernors.org/Publications/LCFPagDoc.pdf and http://www.ct.gov/deep/lib/deep/air/climatechange/lcfs_mou_govs_12-30-09.pdf

${ }^{9}$ For example see http://www.feinstein.senate.gov/public/index.cfm/press-releases?ID=a4499663-9559b897-f40b-7b3ba9c94fcd, http://energy.gov/sites/prod/files/edg/media/Obama_New_Energy_0804.pdf and http://democrats.energycommerce.house.gov/sites/default/files/documents/Transcript-FC-HR-2454ACES-2009-5-18.pdf
} 
Note that like the RFS, an LCFS creates strong incentives for fuel substitution via implicit subsidies for lower carbon fuels 10

\subsection{Carbon trading}

In 2009 the U.S. House of Representatives passed the "American Clean Energy and Security Act," H.R. 2454 otherwise known as the "Waxman-Markey" bill. This legislation, though never approved by the Senate, would have established a broad national carbon trading system including transportation fuels ${ }^{11}$

Under a transportation sector carbon trading system, total emissions summed over all fuels produced must not exceed the cap $\left(\sigma_{C A T}\right)$, formally:

$$
\beta_{1} q_{1}+\beta_{2} q_{2}+\cdots+\beta_{n} q_{n} \leq \sigma_{C A T}
$$

The first-order conditions of the firm's profit maximization problem are:

$$
p=m c_{i}\left(q_{i}\right)+\lambda_{C A T} \beta_{i},
$$

where $\lambda_{C A T}$ is the shadow price of the carbon constraint or equivalently, the price of a carbon permit. Note that each carbon-emitting fuel is taxed in proportion to its carbon emissions. While CAT does provide incentives for substitution by taxing dirtier fuels more, it also provides a greater incentive for reducing fuel consumption due to higher fuel prices ${ }^{12}$ Because producer prices for all fuel increase, equilibrium prices under CAT are larger compared with policies that implicitly or explicitly subsidize ethanol.

\subsection{Ethanol subsidies}

There is a long history of direct subsidies for ethanol production in the US. Until December 2011, ethanol producers received a federal tax credit of 45 cents per gallon under the Volumetric Ethanol Excise Tax Credit (VEETC) ${ }^{13}$ In addition, small volume producers with

\footnotetext{
${ }_{10}$ Holland, Hughes, and Knittel (2009) investigate firm incentives under an LCFS and show that, under very general conditions, an LCFS cannot achieve the efficient allocation of emissions and energy production.

${ }^{11}$ Holland et al. (2013) investigate the political economy of transportation sector carbon policy as a possible explanation of why H.R. 2454 was unsuccessful.

${ }^{12}$ See Table 2 .

${ }^{13}$ Beginning in 1978 ethanol sales were exempt from federal fuel excise taxes. The VEETC, established in 2004, replaced this exemption with a 51 cent per gallon tax credit. The rate was lowered in 2008 to 45 cents per gallon. After several renewals, the VEETC was allowed to expire on December 31, 2011.
} 
less than 60 million gallon capacity also qualify for the Small Ethanol Producer Tax Credit of 10 cents per gallon. For cellulosic ethanol, the 2008 farm bill established a tax credit of 101 cents per gallon, less any applicable VEETC credit. Finally, a number of states provide their own ethanol subsidies or excise tax exemptions.14

Modeling ethanol subsidies is straightforward. Under the assumptions above, a profit maximizing firm produces until marginal cost, less the subsidy $s_{i}$, equals the market clearing price. The firm's first-order conditions for ethanol production are:

$$
p=m c_{i}\left(q_{i}\right)-s_{i}
$$

for each ethanol fuel $i$. For gasoline, the firm produces until marginal cost equals price. Similar to the RFS and LCFS, direct subsidies provide a large incentive for fuel substitution. Our simulations below assume gasoline supply is perfectly elastic. As a consequence, ethanol subsidies do not change the equilibrium fuel price and therefore, provide no incentive for reduced fuel consumption.

\section{Innovation}

Without new technologies for producing low-carbon fuels, reducing carbon emissions will be quite costly. Thus, one of the key features of any carbon policy will be how well it provides incentives for innovation. Overall, the importance of innovation is highlighted by the fact that the primary low-carbon fuels analyzed in this paper, cellulosic ethanols, are not currently produced on a commercial scale.

Innovation is an important area of public concern due to market failures associated with innovation. In order for innovation incentives to match the social gains from innovation, all the benefits would need to accrue to the innovator. Unfortunately this is rarely the case. First, innovation may result in lower prices. If these consumer surplus gains are not captured by the innovator, e.g., if the innovator cannot perfectly price discriminate, then innovation incentives can be too small. Second, knowledge is a public good. If an innovator discovers a process which reduces the costs of other firms, these spillover benefits would not accrue to the innovator and innovation incentives would be too small. Finally, innovation incentives can be too large if there is "business stealing" whereby the innovator merely receives profits which would have accrued to another firm without increasing social surplus.

\footnotetext{
${ }^{14}$ For examples see http://www.afdc.energy.gov/laws/state.
} 
These market failures have led to substantial public involvement in innovation including the patent system, support for innovation through federal tax credits, and direct public investment in research. Innovation in energy receives particular attention, for example, through Department of Energy funding and the national laboratories.

We analyze three different types of innovation: new technologies, cost reducing innovation, and carbon reducing innovation. The new technologies we analyze are cellulosic ethanol from the various feedstocks. Currently, cellulosic ethanol is not produced at commercial scale and a suite of innovations will be required to produce cellulosic ethanol commercially. To analyze the benefits of the entire suite of innovations necessary to allow production of cellulosic ethanol, we simply compare the market equilibria with and without supply from the cellulosic ethanol feedstocks. Next, to analyze cost reducing innovation, we compare the market equilibria with and without a shift in the cellulosic supply curves (marginal cost curves). Our supply curves are based on engineers' projections for future technologies after years of research and development $(R \& D)$. Actual $R \& D$ could be less than expected leading to higher costs. To investigate gains from reducing costs, we analyze a counterfactual where cellulosic ethanol costs are 20 percent higher than our preferred supply curves. Finally, to analyze emissions reducing innovation, we compare the market equilibria with higher and lower carbon emissions rates, $\beta_{i}$ 's. Fuel carbon intensities might be reduced, for example, through the use of new agricultural or production processes.

For each type of innovation and for the different carbon policies, we calculate several measures of gains. First, we calculate the social surplus gain, which is found by simply comparing the social surplus with and without innovation. The social surplus gain is the social willingness to pay for the innovation and captures and gains or losses to consumers as well as any increases or decreases in producer profits. The social surplus gain is the benefit measure which would be used in a benefit-cost analysis of a policy which fostered the innovation. Second, we calculate the distributions of the gains across consumers, cellulosic ethanol producers, and corn ethanol producers ${ }^{15}$ The distribution of gains tells us whether the innovators' incentives are too weak, too strong, or exactly matches the social gains. For example, if the gains to the cellulosic ethanol producers exceed the social gain under a certain policy, then the private innovation incentive is too strong. The distribution of gains also tells us whether we might expect groups to lobby for or against policies supporting that type of innovation. For example, if lowering the costs of cellulosic ethanol leads to large consumer surplus gains under a CAT, but not under the RFS, then we might expect consumers to be more supportive of cost reducing innovation under a CAT than under the RFS. Third, we

\footnotetext{
${ }^{15} \mathrm{By}$ construction, gasoline producers receive no rents.
} 
calculate the marginal incentives to innovate by improving emissions rates. This marginal incentive measures the gains a price-taking firm could expect from a marginal innovation under each of the policies. This marginal incentive can be compared to the social marginal incentive and may be too large or too small.

The marginal incentives may differ from the social marginal incentive and may differ from the gains to cellulosic producers since the gains include equilibrium effects. To illustrate, consider the marginal incentives and equilibrium effects under CAT and the LCFS for innovation in emissions rates ${ }^{16}$ The social planner's problem is :

$$
\max _{q_{i}} U\left(q_{i}\right)-C\left(q_{i}\right)-\tau \beta_{i} q_{i}
$$

where, $\tau$ is the social cost of carbon. $U\left(q_{i}\right)$ captures the benefits of consumption of fuel $i$. As before, $\beta_{i}$ is the emission rate of fuel $i$ and $C\left(q_{i}\right)$ are costs. By the envelope theorem, the social marginal incentive for innovation in emissions rate is $\frac{\partial L}{\partial \beta}=\tau q_{i}^{*}$. Under CAT, Equation 6 implies that the incentive to reduce the carbon emissions rate is $\lambda_{C A T} q_{i}$, again by the envelope theorem. If the carbon cap if set optimally, $\lambda_{C A T}=\tau$, the efficient incentive is obtained. Under the LCFS, the incentive to reduce the carbon emissions rate is $\lambda_{L C F S} q_{i}$, which can be too large or too small 17 Using these results, we calculate producers' marginal incentives to improve emissions rates for each of the fuels in our simulation 18

These marginal effects represent a producer's private gains from reducing fuel carbon intensity marginally. If the innovation is widespread, e.g., if the firm is large or if the innovation spills over to other firms, then the innovation may affect prices and output. To see this, first consider the firm's constrained profit maximization problem under CAT. For exposition, we focus on one fuel $i$, such that:

$$
\pi=p q_{i}-c_{i}\left(q_{i}\right)-\lambda_{C A T} \beta_{i} q_{i}
$$

where $\lambda_{C A T}$ is the price of a carbon permit under CAT. Taking the total derivative with respect to the emission rate $\beta_{i}$ and grouping terms yields:

$$
\left.\frac{d \pi}{d \beta_{i}}=\left[p-m c_{i}\left(q_{i}\right)-\lambda_{C A T} \beta_{i}\right)\right] \frac{\partial q_{i}}{\partial \beta_{i}}+q_{i}\left[\frac{\partial p}{\partial \beta_{i}}-\beta_{i} \frac{\partial \lambda_{C A T}}{\partial \beta_{i}}\right]-\lambda_{C A T} q_{i}
$$

\footnotetext{
${ }^{16}$ Because the RFS and subsidies do not explicitly consider carbon, there is no incentive for firms to reduce emissions under these policies.

${ }^{17}$ See Holland, Hughes, and Knittel 2009 ) for a further discussion of incentives under the LCFS.

18 Montero (2002) shows that pollution taxes and permits provide equal incentives for innovation when output and permit markets are competitive.
} 
If innovation does not affect prices and output, then Equation 10 collapses to the last term, which is equal to the private incentive above $\left(\lambda_{C A T} q_{i}\right)$. If innovation does affect prices and output, then the first term in Equation 10 captures the change in profit from $\beta_{i}$ 's effect on output, and the second term captures the marginal effects of $\beta_{i}$ on prices. Therefore, the overall effect of innovation on firm's profits depends not only $\lambda_{C A T} q_{i}$ but also on how changes in $\beta_{i}$ affects quantities and prices.

Equations 11 and 12 are the analogous expressions for the LCFS. The firm's profit maximization problem for fuel $i$ is:

$$
\pi=p q_{i}-c_{i}\left(q_{q}\right)-\lambda_{L C F S}\left(\beta_{i}-\sigma\right) q_{i}
$$

Where $\lambda_{L C F S}$ is the price of a carbon permit under the LCFS. Taking the total derivative with respect to $\beta_{i}$ yields:

$$
\frac{d \pi}{d \beta_{i}}=\left[p-m c_{i}\left(q_{i}\right)+\lambda_{L C F S}\left(\sigma-\beta_{i}\right)\right] \frac{\partial q_{i}}{\partial \beta_{i}}+q_{i}\left[\frac{\partial p}{\partial \beta_{i}}+\frac{\partial \lambda_{L C F S}}{\partial \beta_{i}}\left(\sigma-\beta_{i}\right)\right]-\lambda_{L C F S} q_{i} .
$$

To explore gains and loses from innovation in fuel emissions, Section 5.4 focus on counterfactuals where the emission rates of corn and cellulosic ethanol are 10 percentage points higher than our preferred estimates.

\section{Simulation methodology}

To understand the impact of biofuel policies on agricultural production, land-use and emissions, we combine detailed data on agricultural resources with engineering models for ethanol production. We construct county-level supply curves for corn ethanol and six different types of cellulosic ethanol. From these relationships we estimate county-level biomass consumption and land-use as well as aggregate carbon emissions and land-use related externalities. We simulate equilibrium outcomes under a business as usual scenario (BAU) and under a RFS, an LCFS, CAT, and direct subsidies (SUBS). We follow the approach in Holland et al. (2013). Here, we briefly summarize the main assumptions and methods used in our analysis.

\subsection{Supply curves}

We construct supply curves for corn ethanol and six different cellulosic ethanol fuels produced from agricultural residues, forest waste, municipal solid waste, orchard and vineyard waste 
and herbaceous energy crops. The supply curves are based on engineering models for ethanol production costs and use detailed county-level data on agricultural production and waste resources. The industry is modeled as a set of profit-maximizing, price-taking firms with perfect information. See Parker (2011) and Parker (2012) for more details.

We begin by discussing the biomass resource data. County-level estimates for corn production are based on the aggregate relationship between corn prices and harvests. We forecast total US corn production based on projections from United States Department of Agriculture (2010). Each county's share of total production is proportional to its share of historical production as reported by National Agricultural Statistics Service (2009). Total corn ethanol production is constrained at 15 billion gallons per year in compliance with the RFS.

Biomass resources for cellulosic ethanol production are obtained from a variety of sources including energy crops and wastes. For energy crops, we focus on herbaceous energy crops (switchgrass) and farmed trees. We assume herbaceous energy crops may only be grown on marginal lands, defined as idle cropland or cropland used for pasture. Switchgrass resources are estimated by multiplying the amount of marginal land within a county, based on the 2007 Census of Agriculture (National Agricultural Statistics Service, 2009), by estimated switchgrass production yields from Wullschleger et al. (2010). Farmed tree supply is based on recent US Forest Service estimates for pulpwood production.19

We also consider orchard and vineyard waste and two types of agricultural residues: corn stover and wheat straw, that are by-products of grain production. Recently, agronomists have estimated the collection costs and availability of a variety of biomass resources based on historical yields, land areas, and production practices. Our wheat straw, orchard and vineyard resource estimates are from Nelson (2010). The corn stover data are from Graham et al. (2007). Finally, we consider the possibility of converting municipal solid waste to ethanol. We estimate the available resource using state-level per capita waste production statistics (Simmons et al., 2006), the composition of wastes currently landfilled (U.S. Environmental Protection Agency, 2007), transportation, and waste sorting costs.

Ethanol production costs are based on engineering models for three technologies. Corn ethanol is produced by either wet-mill or dry-mill processes. Production costs for corn ethanol are taken from Gallagher, Brubaker, and Shapouri (2005), Gallagher and Shapouri (2005), and Butzen and Hobbs (2002). We assume all existing plants continue to operate and take their locations as fixed (Renewable Fuels Association, 2009). In addition to existing

\footnotetext{
${ }^{19}$ Obtained via personal communication with Ken Skog at the USFS.
} 
plants, our optimization model sites new plants based on energy prices, feedstock and transportation costs. Due to the relative costs of the technologies, we assume all new facilities are dry mill plants. Energy crops and waste feedstocks are converted to ethanol using a dilute acid enzymatic hydrolysis and fermentation technology. Production costs for cellulosic ethanol are modeled using Wooley et al. (1999); Hamelinck, Hooijdonk, and Faaij (2005); Aden et al. (2002); McAloon et al. (2000). Because cellulosic ethanol technology is not currently at production scale, cost estimates are based on future projections and represent significant advances from the current state of the industry.

The model combines these data in a mixed integer linear programming model which maximizes firm profits by choosing plant location, production technology and output conditional on fuel price, biomass resources, conversion and transportation costs. Re-optimizing the model for a range of fuel prices yields county-level supply curve estimates for each fuel which we then aggregate to the national level. The resulting supply curves are shown in Figure 1. Note that different prices correspond to different levels of plant production as well as different industry configurations in terms of the number, size and location of production facilities. Because these parameters are variable, the supply curves represent estimates of long-run biofuel supply.

\subsection{GHG emissions intensities}

Quantifying the emissions intensities of each fuel poses several challenges. First, because biofuels are produced from crops which remove carbon dioxide from the atmosphere, estimating emissions requires modeling the fuel "life-cycle" impacts from cultivation to production to combustion. Second, emissions impacts are more uncertain if one considers "indirect land-use effects" where increased cultivation of energy crops leads to new or displaced production on previously fallow lands. While indirect effects are controversial, recent work by Searchinger et al. (2008); California Air Resources Board (2009); Fargione et al. (2009); Hertel et al. (2010); Dumortier et al. (2011) suggests that large amounts of sequestered carbon may be released when new lands are put into production. Indirect emissions from corn and cellulosic ethanol production could add between $44 \%$ and $98 \%$ to the emissions intensities of these fuels (California Air Resources Board, 2009). Third, carbon emissions for cellulosic pathways may change as the industry matures.

Because of these challenges, there is no simple accounting of carbon intensities for the different ethanol fuels. Instead, we rely on estimates from life-cycle analyses. Table 1 summarizes estimates from recent studies. We present emissions rates normalized by the 
emissions intensity of gasoline. For example, an emissions intensity of 0.90 implies emissions 10 percent lower than gasoline. We see that there is substantial variation across the estimates. For ethanol produced from municipal solid waste, estimated emissions intensities range from 0.04 (Zhang, Joshi, and MacLean, 2010) to 0.35 (Kalogo et al., 2007). For agricultural residues, estimates range from -0.29 (U.S. Environmental Protection Agency, 2010) to 0.16 (Spatari, Zhang, and MacLean, 2007). ${ }^{20}$ Even in the case for the relatively more established corn ethanol production process, estimates vary substantially with intensities ranging from 0.79 (U.S. Environmental Protection Agency, 2010), a 21 percent reduction in emissions, to 1.04 (California Air Resources Board, 2009), a 4 percent increase in emissions relative to gasoline.

Our approach in dealing with this uncertainty is twofold. First, our simulations assume emissions intensities for each fuel that fall conservatively in the range of those reported in the literature. We use 0.80 for corn based ethanol and 0.25 and 0.20 for ethanol produced from herbaceous energy crops and waste biomass. Then, in a series of robustness checks reported in Appendix B, we verify that our results do not depend on these assumptions.

\subsection{Land use calculations}

In our data, the feedstocks with the largest potential for large land-use shifts are corn and herbaceous energy crops. We assume that there are no land use effects associated with the use of waste biomass for ethanol production 212 This assumption seems reasonable given collection costs and the relatively small quantity of waste biomass available.

Each ethanol supply curve is based on production at discrete plants optimally sited across the U.S. by our linear optimization model. The quantity of biomass required to produce a gallon of ethanol is determined by ethanol conversion efficiency factors assigned to each production technology described above. For each ethanol plant and each fuel type, the total quantity of biomass consumed is known for every point on the supply curve. To calculate the total amount of land required to supply biomass to each plant, we use county-level crop yield data to convert biomass tons to acres planted.

Corn yields are estimated by increasing the current county level yields National Agricultural Statistics Service, 2009) uniformly at the rate projected for the national average (United States Department of Agriculture, 2010). Switchgrass yields were modeled by Oak

\footnotetext{
${ }^{20}$ Negative emissions intensities occur when fuels are credited for electricity co-generation at ethanol plants.

${ }^{21}$ For example, farmers that sell orchard and vineyard waste to ethanol plants do not expand their orchards as a result of the reduced cost of waste disposal.
} 
Ridge National Laboratory for both lowland and upland varieties of switchgrass. To approximate yields for switchgrass grown on marginal lands, our calculations use upland yields. Pulpwood yields are from the US Forest Service.

We calculate both the total area used in energy crop production and the "land-use intensity" under each policy. We define land use intensity as the total number of acres used in energy crop production divided by total land area in a given county. This approach provides a consistent basis for comparison across counties and highlights the regions where land use shifts are occurring. Using total land area as the basis for comparison also illustrates the tradeoffs that occur when marginal lands are put into production 22

We calculate land areas and intensities for all energy crops, corn plus switchgrass and farmed trees, and for corn alone. This distinction is useful for two reasons. First, farmland used for corn production is a substitute for land used for food crops. Herbaceous energy crops and pulpwood are assumed to be grown on land not used for production of food or other cultivated crops. Therefore, one would expect food price and indirect land use effects from corn to be larger than for crops grown on marginal land. Second, corn may be raised using more intensive farming practices leading to more fertilizer use, irrigation, erosion, etc., compared to herbaceous crops and trees. Below we show both the changes in land areas for each crop category as well the the geographic distribution of energy crop intensity.

\subsection{Simulating transportation carbon policies}

We simulate long-run equilibrium outcomes under each of the different carbon policies and in a business as usual scenario with no carbon policy. Ethanol production is characterized by our seven supply curves. We model long-run gasoline supply as perfectly elastic at a price of $\$ 2.75$ per gallon ${ }^{23}$ This assumption seems reasonable given that the carbon policies reduce gasoline production, suggesting refinery capacity constraints are unlikely to be a factor in the long-run. However, this assumption would be violated if long-run average costs are upward sloping, for instance due to heterogeneity in refineries' access to inputs or demand. Total fuel demand is modeled as constant elasticity, with an elasticity of 0.5 and calibrated to US EIA projected fuel consumption of 140 billion gge per year at our baseline price of $\$ 2.75$ per gge. ${ }^{24}$ We assume the fuels are perfect substitutes after taking into account the volumetric

\footnotetext{
${ }^{22}$ As opposed to comparisons based on the number of arable acres within the county, for example.

${ }^{23}$ I.e. the assumption of perfectly elastic supply implies that gasoline production is determined by the demand for transportation fuel and the total level of ethanol production under each policy.

${ }^{24}$ We assume excise taxes are constant throughout the period at $\$ 0.48$ per gallon and are applied to both gasoline and ethanol. We assume distribution and retail costs of $\$ 0.15$ per gallon for both fuels.
} 
energy densities of gasoline and ethanol.

For each of the policies described in Section 2 and the BAU scenario we calculate the equilibrium consumer and producer prices that equate supply and demand. Under BAU, the equilibrium price is determined by the long-run supply of gasoline at $\$ 2.75$. For the RFS, we calculate the producer prices that satisfy the three different RFS constraints and equate total fuel supply and demand. We design the LCFS and CAT policies to achieve the same total reduction in carbon emissions as the RFS. Specifically, the LCFS producer price vector includes a carbon price that reflects the emissions intensity of each fuel and the intensity target. We adjust the intensity target until overall carbon emissions match the RFS. Under CAT, we simply set the carbon cap at the RFS level. For ethanol subsidies, the consumer price is the marginal cost of gasoline. Producer prices for ethanol are adjusted by the subsidy amounts. We use the recent VEETC ( $\$ 0.45$ per gallon) and cellulosic (\$1.01 per gallon) subsidy levels rather than targeting the same emissions reduction as the RFS.

Because our ethanol supply curves are discontinuous, we solve for equilibrium under each policy using a numerical simulation algorithm. In the BAU case, ethanol production is determined by price and the ethanol supply curves. Gasoline production is the amount of additional fuel required to clear the market. Under the RFS, the simulation consists of two separate search algorithms. The first set determines the RFS ratios that satisfy the three volumetric mandates. The second set calculates the RIN prices that satisfy the RFS ratios for each fuel. Gasoline production again fills the residual demand. The LCFS simulation loops over the LCFS shadow price $\lambda_{L C F S}$ until the LCFS constraint is satisfied. On outer loop solves for the LCFS constraint the matches carbon emissions to the RFS level. For CAT, the carbon price is adjusted until total emissions equal the cap, where again the cap equals emissions under the RFS.

\section{Results}

We begin by comparing prices, emissions and ethanol production under each policy. Next, we compare land use changes and investigate the distribution of energy crop production across counties. Because we have information on the type of land used, we also report this separately for cultivated and uncultivated lands. Given prior estimates of costs associated with land use changes, we calculate what these changes imply for non-GHG externalities. We also report land use externalities on a per GHG-abated basis allowing the reader to compare these costs with estimates of the social cost of carbon. We investigate the robustness of each 
policy to errors in assigning carbon emission intensities to each fuel, and quantify the cost of any uncontrolled carbon emissions. Finally, we calculate incentives for innovation.

\subsection{Ethanol production and the Blend Wall}

Table 2 shows energy prices, fuel production, and emissions under each policy. The 2022 RFS leads to a 10.2 percent reduction in carbon emissions compared with BAU. By design, the LCFS and CAT systems achieve the same reduction. However, the reduction mechanisms differ across policies. Energy prices are substantially higher under CAT at $\$ 3.23$ per gge. Because demand is downward sloping, higher prices imply less fuel is consumed under CAT, 129.1 billion gge, compared to the other policies, 135 to 140 billion gge. This means with CAT, less ethanol is required to achieve the same reduction in emissions. Across policies, we see ethanol quantity increases by 3.8 billion gge under CAT compared with 14.9 to 18.5 billion under the alternatives 25

Greater substitution to ethanol under the alternatives to CAT creates inefficiency in terms of higher abatement costs. To see this, Figure 2 shows marginal abatement costs and emissions reduction mechanisms for CAT and a LCFS when we vary abatement levels. The heavy black line shows the marginal abatement cost under each policy calculated by running our simulation model for range of carbon prices and determining the level of carbon emissions. The light line depicts marginal abatement costs assuming zero fuel substitution. ${ }^{26}$ For a $10.2 \%$ reduction in emissions, the marginal abatement costs under CAT and the LCFS are $\$ 40.83$ per $\mathrm{MTCO}_{2} \mathrm{e}$ and $\$ 189.70$ per $\mathrm{MTCO}_{2} \mathrm{e}$, respectively. Under CAT, a substantially larger portion of the emissions reduction comes from reduced fuel demand. Under the LCFS, a much larger share of abatement comes from fuel substitution, i.e. the horizontal distance between the light and heavy curves in Figure 2. This finding highlights the main difference between CAT and the other policies under consideration, namely that emissions reductions under CAT come from reduced fuel consumption while direct subsidies, the RFS and LCFS result in more substitution towards ethanol.

Higher ethanol production raises concerns about whether or not the ethanol can be effectively utilized by the existing vehicle fleet. Conventional vehicles can safely use ethanolgasoline blends of up to 10 percent (E10). Using substantially higher ethanol blends requires

\footnotetext{
${ }^{25}$ These large shifts in fuel production translate into large changes in resource consumption. We summarize biomass feedstock consumption under the different policies in Appendix A

${ }^{26}$ We calculate this curve by assuming ethanol has the same emissions intensity as gasoline. In this case, carbon reductions come only from reductions in fuel consumption due to increased fuel prices and the elasticity of fuel demand.
} 
a "flex-fuel vehicle" with a modified fuel system to efficiently combust the higher ethanol blends. Although flex-fuel vehicles are becoming more common, the current vehicle fleet limits the amount of ethanol that can be used. This percentage, called the "blend wall," depends on the existing vehicle fleet and is approximately 10 to 12 percent.

The different policies require blending different proportions of ethanol. These ethanol blend percentages are presented in Table 2. Under the RFS, LCFS, and subsidies, the blends range from E21 to E24. These percentages are currently outside the blend wall and would require a substantial change in the vehicle fleet in order to utilize that much ethanol. ${ }^{27}$ On the other hand, under CAT the quantities correspond to an effective blend of 10 percent ethanol by volume (E10). Thus, ethanol production under CAT is likely within the blend wall and would not require changes to the existing vehicle fleet, but other policies could require substantial changes to the vehicle fleet.

Production of the different types of ethanol also varies considerably across policies. Under the RFS and subsidies, corn ethanol production increases by 8 to 9 billion gge per year relative to BAU. Under the LCFS, the increase is roughly half as much. Under CAT, no additional corn ethanol is produced. The RFS, LCFS, and subsidy policies all result in large increases in cellulosic ethanol production from energy crops and waste feedstocks. Under CAT, the majority of new ethanol production comes from waste resources. Overall, the large increases in ethanol production from energy crops suggests large shifts in agricultural activity and land-use under the alternatives to CAT.

\subsection{Land-Use Changes}

Land intensities for energy crops are illustrated in Figures 3 and 4 . Figure 3 shows intensities for all energy crops, i.e corn, switchgrass and pulpwood, under the 2022 RFS, LCFS, CAT and subsidies. Energy crop production under CAT is modest and concentrated primarily in the Midwest. In stark contrast, the LCFS and RFS result in substantial amounts of land dedicated to energy crop production. Intensities under direct subsidies are quite similar to the RFS, though the emissions reduction is considerable smaller. Figure 4 shows land intensities for corn under each policy. Effects under the RFS are large with many Midwest counties devoting large land fractions to corn production. The LCFS also results in large increases in corn production. In contrast, the CAT system leads to relatively small changes in corn land intensity.

\footnotetext{
${ }^{27}$ Below we assume that producers in 2022 are not constrained by the current "blend wall". This could substantially underestimate the costs of any policy which requires ethanol blends beyond this limit.
} 
Table 3 summarizes the distribution of county-level land-use intensity across policies. We define energy-crop counties as those counties that would produce some energy crops - either corn or a cellulosic feedstock - in our model at the highest estimated cost ${ }^{28}$ Under this definition, 2,670 counties of the 3,137 counties in the United States are energy-crop counties. Table 3 summarizes the distributions across energy-crop counties. Under BAU, very little ethanol is produced and thus very few counties have any energy crop production. In fact, over 95 percent of energy-crop counties produce no energy crops under BAU and energy-crop production is concentrated in a few counties one of which devotes 50 percent of the total land area for energy-crop production. Under the RFS, the distribution is quite different. In one county 62 percent of the land area is used for energy-crop production. Five percent of energy-crop counties devote over 26 percent of land area to energy-crop production and 10 percent of counties use over 12 percent. Under subsidies, the distribution is quite similar with intensities of 9.3 percent and 25.4 percent at the 90 th and 95 th percentiles, respectively. Under the LCFS, intensities are somewhat less, but still substantial, with intensities in 5 percent of counties greater than 14.4 percent. In contrast, the distribution under CAT is more like BAU and less than 5 percent of energy-crop counties have any meaningful energy crop acreage.

These high intensities under the RFS, LCFS and subsidies lead to large changes in acreage for energy crop production. Table 4 summarizes total land-use changes, relative to BAU, under each policy. Under CAT, total changes in land-use are modest. Area for energy crops increases 1.2 million acres relative to BAU. There is essentially zero increase in corn acreage. Land-use changes under the LCFS are larger with approximately 14.7 million additional corn acres and 27.6 more total acres relative to BAU. The effects are largest under the RFS which results in 39.0 million additional acres of energy crop production. Approximately 27.7 million additional acres are used for corn production. ${ }^{29}$ Under subsidies, the land use changes are quite similar at 37.7 million addition total acres and 25.7 additional corn acres relative to BAU. To put these numbers in perspective, the total increase in agricultural production under the RFS would occupy and area equal to approximately 9 percent of total US agricultural land (Lubowski et al. (2006)). If this land were a state, it would be ranked the 24th largest in size ahead of Georgia, Illinois, Iowa and New York.

To understand the environmental costs associated with these large land shifts, we rely on

\footnotetext{
${ }^{28}$ The highest estimated cost is $\$ 6.13$ per gge, which corresponds to a maximum wholesale price of $\$ 5.50$ per gge plus $\$ 0.63$ due to taxes, distribution and retail as described in Section 4 .

${ }^{29}$ Our estimates for the land-use effects of the RFS fall in the range of other recent estimates. Chen et al. (2011) find the 2022 RFS increases total acres by 16.95 million and corn acres by 11.47 million. Chakravorty et al. (2013) find the RFS increases US land used for energy crop production by 148 million acres. However, there is no net increase in total cultivated land due to offsetting increases in food production elsewhere.
} 
the results of previous studies. Because it is difficult to obtain estimates for the wide range of environmental effects that may occur, we focus on erosion and habitat loss. Hansen (2007) estimates imply costs from erosion and habitat loss between $\$ 36$ and $\$ 80$ per acre. For corn, we assume each new acre of production increases total US agricultural land by .3 acres..$^{30}$ Based on these studies, we use a range of land-related environmental costs between $\$ 10$ and $\$ 25$ per additional acre of corn production. We conservatively assume that production of herbaceous energy crops and pulpwood have no net environmental impact.31 Additional information on the calculation of these costs is discussed in the Appendix. Finally, we convert costs to dollars per ton of $\mathrm{CO}_{2} \mathrm{e}$ in order to compare with estimates of the social cost of carbon.

Table 5 summarizes costs due to non-carbon externalities stemming from changes in corn production under the various policies. The differences in costs across policies are significant. Under CAT, land use change costs are approximately zero. Under the RFS, LCFS, and subsidies systems, costs range between $\$ 147$ and $\$ 277$ million for the low cost scenario and $\$ 368$ and $\$ 693$ million for the high cost scenario. Per ton of carbon abatement, these costs fall between $\$ 0.89$ and $\$ 2.31$ per $\mathrm{MTCO}_{2}$ e for the low cost scenario and between $\$ 2.22$ and $\$ 5.77$ per $\mathrm{MTCO}_{2} \mathrm{e}$ for the high cost scenario. To put these effects in perspective, under the RFS and subsidies, social costs due to land use changes amount to between 6 percent and 16 percent of the social cost of carbon ${ }^{32}$ Under the LCFS, these costs are between 3 percent and 8 percent of the social cost of carbon. Thus non-carbon externality costs can be substantial under the RFS, LCFS or subsidies, but are negligible under the CAT.

\subsection{Uncontrolled emissions}

As discussed above, the life-cycle emissions of advanced ethanol production technologies are difficult if not impossible to calculate. In particular, carbon emissions associated with direct and indirect land use changes resulting from shifts in agriculture are highly uncertain (Dumortier et al., 2011; Keeney and Hertel, 2009). This creates the possibility of errors in estimating the carbon intensities of different ethanol pathways. Furthermore, emissions

\footnotetext{
${ }^{30}$ This takes into account yield increases and substitution away from other crops. Our value is consistent with recent estimates by Searchinger et al. (2008) who find 0.29 additional acres per new corn acre and Hertel et al. (2010) who find 0.27 additional acres per corn acre.

${ }^{31}$ Our supply curves assume switchgrass is grown on marginal lands without irrigation of chemical fertilizers. Further, we assume production does not substantially increase erosion and switchgrass offers similar wildlife habitat to the land being replaced.

${ }^{32}$ Assuming a value of $\$ 26.3$ per $\mathrm{MTCO}_{2}$ e per Greenstone, Kopits, and Wolverton (2011) for 2020 with a 3 percent discount rate.
} 
intensities under any transportation sector carbon policy are likely to be set as part of a political process. In light of this, we investigate the sensitivity of actual emissions under each policy to errors in the regulated emissions intensity. In particular, we are agnostic about whether the "errors" arise through a higher than expected shock to ex post emissions intensities relative to the regulated emissions intensities which must be set ex ante or through a political process which results in the regulated emissions intensities being lower than the true emissions intensities, e.g., by a political decision to ignore indirect land use effects ${ }^{33}$

We focus on the emissions related to corn ethanol production and the associated land use changes. Imagine a scenario in which the true emissions intensity of corn ethanol is 10 percentage points larger than the regulated intensity, i.e., the true emissions intensity is $\sigma_{\text {corn }}=0.90$ compared to the regulated emissions intensity of $\sigma_{\text {corn }}=0.80$. The equilibrium will be determined by the the regulated emissions intensity, but the welfare effects are calculated from the true emissions intensity. Note that this error could have dramatic effects under some policies. For example, it could mean that corn receives an implicit subsidy (instead of a tax) under the LCFS.

Table 6] summarizes carbon emissions under each scenario. We define uncontrolled emissions as the additional carbon emitted because the true emissions intensity is larger than the regulated emissions intensity specified by policy makers. An intuitive metric of environmental effectiveness is the quantity of uncontrolled emissions as a fraction of the stated reduction in carbon. The effect of the error in emissions intensity is smallest under CAT at approximately 0.7 percent. Under the RFS, LCFS, and subsidies the effects are 7.1 percent, 4.0 percent, and 9.9 percent, respectively.

These effects are economically significant. We estimate the additional carbon damages due to uncontrolled emissions by adopting the central estimate of the Greenstone, Kopits, and Wolverton (2011). At a carbon cost of $\$ 26.3$ per $\mathrm{MTCO}_{2} \mathrm{e}$, damages due to uncontrolled emissions range from approximately $\$ 30$ million per year under CAT to over $\$ 307.7$ million per year under the RFS. In summary, errors in the true greenhouse gas content of biofuels relative to the regulated content are magnified under the RFS, LCFS, and subsidies, but are negligible under CAT.

\footnotetext{
${ }^{33}$ For simplicity we imagine a regulated intensity which understates true emissions. From a welfare perspective, an overstatement could also be costly if it resulted in a level of ethanol production that was inefficiently too low. However, given the existence of other negative externalities associated with land use changes, the welfare implications are likely to be asymmetric.
} 


\subsection{Gains from innovation}

We now consider gains from innovation under each policy following the framework developed in Section 3. We begin with gains from the development of cellulosic ethanol. Table 7 shows surplus with and without the six types of cellulosic ethanol under BAU, LCFS, CAT, and subsidies 3455 For a given policy, the gains to society from developing cellulosic ethanol depend on two factors. First, gains will be larger the more a policy relies on cellulosic ethanol. For example, BAU does not require much cellulosic ethanol, and hence the gains from developing cellulosic ethanol are modest: $\$ 0.91$ billion. The other policies rely much more on cellulosic ethanol. CAT in particular relies most heavily on cellulosic ethanol (almost no corn ethanol is produced under CAT) and hence the social gains under CAT are large: $\$ 4.38$ billion. Second, gains can be larger or smaller depending on whether cellulosic ethanol worsens or improves the efficiency of a given policy. For example, under the subsidy policy cellulosic ethanol receives substantial subsidies. By developing cellulosic ethanol technology some low-cost cellulosic ethanol is produced. However, the subsidies also induce substantial cellulosic ethanol to be produced which is more costly than the alternatives. Thus developing cellulosic technology worsens the efficiency of the subsidies. In fact, Table 7 shows that the social surplus gain from developing cellulosic ethanol is negative with subsidies. In other words, society would be better off without cellulosic ethanol under the subsidy policy. The LCFS lies somewhere between the two extremes of CAT and the subsidy policy: the LCFS relies heavily on cellulosic ethanol but is an inefficient policy.

We now turn to the distribution of the gains across the policies. The incentives for developing cellulosic ethanol can be insufficient or excessive depending on whether or not the surplus gains to the cellulosic ethanol producers match the social gains. Under BAU, the incentives align since gasoline is the marginal fuel, prices are not changed by developing cellulosic ethanol, and cellulosic ethanol producers capture the entire social gains. However, this is the exception rather than the rule. For example, in CAT, the fuel price does not increase as much with innovation, thus consumers gain and cellulosic ethanol producers capture only $\$ 3.31$ billion of the $\$ 4.38$ billion social surplus gains from innovation. In this case, cellulosic producers would not be willing to undertake innovation that costs more than $\$ 3.31$ billion, even though that innovation might be socially beneficial, i.e., might cost less than $\$ 4.38$ billion 36

\footnotetext{
${ }^{34}$ We cannot analyze the RFS since the RFS explicitly requires production of cellulosic ethanol.

${ }^{35}$ Each of the LCFS and CAT simulations - with and without the innovation - is designed to achieve the same carbon emissions as the RFS baseline.

${ }^{36}$ In CAT, there is also extensive carbon market revenue. This carbon market revenue is smaller with innovation but still would be substantial enough ( $\$ 59.35$ billion) to finance efficient innovation.
} 
For the LCFS and subsidies, the interaction between innovation and the efficiency of the policies makes for inefficient incentives and clear winners and losers. Under the subsidy policy, the fuel price is unchanged so the entire subsidy of $\$ 21.72$ billion comes from the government. But these transfers result in only $\$ 17.29$ billion in profit for the cellulosic producers, thus resulting in a deadweight loss of $\$ 4.43$ billion. In this case the cellulosic producer's profits vastly exceed the social gains from innovation, which are negative. This implies cellulosic producers would be willing to undertake socially inefficient innovation just to capture additional subsidy dollars.

Under the LCFS, innovation prevents the fuel price from rising as high, so consumers benefit from the innovation. However, corn ethanol producers are harmed by cellulosic innovation under the LCFS. Recall that the LCFS has an implicit subsidy to fuels with relatively low carbon intensities. In the absence of innovation in cellulosic ethanol, corn ethanol is the low carbon fuel and as such receives a subsidy. Corn ethanol loses this subsidy when cellulosic ethanol is commercialized 37 Much of the corn producer's lost surplus is captured by the cellulosic ethanol producers so that their gains are quite substantial: $\$ 20.56$ billion. Note that this implies cellulosic ethanol producers would be willing to pay (e.g., in licensing fees) more than the entire social benefit from innovation ( $\$ 2.61$ billion). Thus the private innovation incentives under the LCFS are too large and could result in investment beyond the socially efficient level 38

Finally, the development of cellulosic ethanol lowers costs of carbon reductions under the LCFS, CAT, and subsidies. We define average abatement cost as the total change in private surplus, net of carbon market revenues or subsidy payments, divided by carbon abatement. Average abatement costs under the LCFS fall from $\$ 58.87$ per $\mathrm{MTCO}_{2}$ e to $\$ 48.58$ and from $\$ 40.54$ per $\mathrm{MTCO}_{2}$ e to $\$ 19.52$ under CAT with the development of cellulosic ethanol. Under subsidies, average abatement costs fall from $\$ 194.45$ to $\$ 82.30$ per $\mathrm{MTCO}_{2} \mathrm{e}$.

Next, we consider gains from a reduction in ethanol costs. Table 8 compares equilibrium under our preferred supply curves (with innovation) to the equilibrium under the counterfactual where cellulosic ethanol costs are 20 percent higher (without innovation) ${ }^{39}$ As before, the gains from innovation depend on how heavily the policy relies upon cellulosic ethanol and on how innovation interacts with existing distortions.

\footnotetext{
${ }^{37}$ Note that corn ethanol producers gain under the LCFS even with innovation they just don't gain as much as they would have in the absence of innovation.

${ }^{38}$ This result is akin to the business-stealing effect which can lead to excess entry beyond the socially optimal level of entry.

${ }^{39}$ Because we assume all producers realize the same percentage costs reductions from innovation, this can be thought of as publicly provided innovation or as innovation with complete spillovers.
} 
For BAU and CAT, the social gains from decreasing cellulosic costs are straightforward. BAU does not rely heavily on cellulosic ethanol and thus the gains from lowering its costs are modest and less than the full gains from developing cellulosic ethanol. Moreover, the gains accrue entirely to the cellulosic ethanol producers, and the innovation incentives are efficient. Under CAT, the gains are more substantial, since CAT relies more heavily on cellulosic ethanol. However, the innovation incentives are not efficient since a proportion of the gains are captured by consumers. Note that the gains from lowering costs are less than the full gains from developing cellulosic ethanol.

As above, the interaction between cost-reducing innovation and the efficiency of the other policies makes for inefficient incentives and clear winners and losers. Under subsidies, cost-reducing innovation increases surplus by lowering the cost of the inframarginal cellulosic ethanol, on one hand, but decreases surplus by causing additional high-cost cellulosic ethanol to be produced, on the other 40 Table 8 shows that these effects result in a net social gain from the cost-reducing innovation of $\$ 3.91$ billion. As above, this yields an excessive incentive for innovation since the ethanol producers' gains exceed the social gains. Note also the odd comparison of the results in Table 7 and Table 8. Under the subsidy, it is not socially beneficial to develop cellulosic ethanol, but once it is developed (and has substantial inframarginal production) it is socially beneficial to reduce its costs.

For the LCFS, the social benefits from cost-reducing innovation are quite substantial and exceed the gains to cellulosic producers implying that the innovation incentive is insufficient. This social surplus gain from cost-reducing innovation arises because reducing the costs of inframarginal cellulosic ethanol production increases surplus by more than the additional cellulosic ethanol production decreases surplus. As with the subsidy, the results in Table 7 and Table 8 yield an odd comparison: it is more socially beneficial to reduce costs of cellulosic ethanol by $20 \%$ than it is to develop it 41

The gains to cost-reducing innovation under the RFS are interesting. Since the RFS mandates a specific amount of cellulosic ethanol, the social gains to reducing its costs are large. However, since the ethanol producers are required to produce and must be sufficiently compensated through the RIN market, the cellulosic ethanol producers are largely indifferent to cost reductions which primarily benefit consumers. In fact, the results of Table 8 show

\footnotetext{
${ }^{40}$ Intuitively, subsidies create deadweight loss when the marginal private cost of production exceeds marginal private benefits. Without innovation, marginal private costs are higher and deadweight loss is less. Higher costs in this case reduce the inefficiency of the subsidy in the same way as would a tax on production.

${ }^{41}$ We explore this result further in Appendix Table 7. Since developing cellulosic ethanol is a limiting case of reducing cellulosic ethanol costs, we analyze more extreme cost reductions in Appendix Table 7 and show that they smoothly approach the results in Table 7.
} 
that cellulosic ethanol producers could actually be harmed by the cost-reducing innovation and thus might not only have an insufficient incentive to reduce costs, but may even have an incentive to increase costs 42 Across policies, innovation lowers average abatement costs between $\$ 10.74$ and $\$ 29.94$ per $\mathrm{MTCO}_{2} \mathrm{e}$.

Next, we investigate innovation in fuel emission intensities. Since the equilibria under the RFS and subsidies don't depend on the emissions intensities, we focus on the LCFS and CAT ${ }^{43}$ We consider both the marginal private incentives for improving fuel emissions rates and social gains from carbon reducing innovation. Beginning with the marginal incentives, from Section 3 we know the marginal incentive to reduce carbon emissions from fuel $i$ under the LCFS is $\lambda_{L C F S} q_{i}{ }^{44}$ The marginal social benefit from reducing emissions is $\tau q_{i}$. Therefore, whether the LCFS provides the correct marginal incentive depends on whether $\lambda_{L C F S}$ is larger or smaller than the social cost of carbon $\tau$. Under an LCFS that reduces carbon emissions by $10.2 \%, \lambda_{L C F S}=\$ 189.70$, compared with a carbon price of $\lambda_{C A T}=$ $\$ 40.83$ under CAT (Figure 2). Given recent estimates for the social cost of carbon of $\$ 26.3$ per $\mathrm{MTCO}_{2} \mathrm{e}$ Greenstone, Kopits, and Wolverton (2011), the marginal incentive for carbon reducing innovation under the LCFS is too large. We note that while CAT can provide the correct marginal incentives, at this level of abatement the marginal incentive under CAT also appears too large. However, from Figure 2 we see that even at abatement levels where CAT incentives are correct (about 6\%), the marginal incentive under the LCFS is still several times larger. Of course, larger incentives under the LCFS or subsidies may help offset other market failures such as innovation spillovers. Because the magnitude of innovation spillovers in ethanol production is unknown, it is impossible to say whether these incentives are too large or too small. In general, it is unlikely that these policies will provide the correct incentives, and targeting spillovers directly with R\&D subsidies or strengthened intellectual property may lead to lower economic inefficiencies.

Table 9 presents the social gains and the distribution of gains from carbon-reducing innovation. The columns labeled "corn" show a counterfactual where the emission rate of corn ethanol is 10 percentage points higher than our preferred estimates. The columns labelled "cell." use a counterfactual where cellulosic emissions are 10 percentage points higher

\footnotetext{
${ }^{42}$ These producer surplus loses come from our assumption that innovation leads to a 20 percent reduction in costs for all producers. In this case, the price reduction (which is determined by the marginal producer) is larger than the cost reduction of the inframarginal producers, which implies lost profit. If instead innovation caused costs for all producers to fall by a constant dollar amount per gge, gains to cellulosic producers would be exactly zero.

${ }^{43}$ Improving emissions intensities under the RFS and subsidies would result in less carbon, so the social benefit would be the benefit of the carbon reduction. Here we hold the carbon reduction constant.

${ }^{44}$ If a firm appropriated all the gains from innovation, the marginal private incentive for reducing the cost to produce fuel $i$ would be $q_{i}$, which is larger under the RFS, LCFS and subsidies compared with CAT.
} 
than our preferred estimates. Overall, the effects of innovation are more modest than in the other scenarios. Under CAT, social gains from innovation are straightforward. Consumers gain from innovation by way of lower fuel prices. Carbon market revenue decreases from carbon-reducing innovation. Overall, social gains are positive.

Under the LCFS, the results are more interesting. Social gains from reducing corn ethanol emissions are negative. Lower corn emissions increases corn production but lowers the implicit subsidy for all ethanol producers. As a result, large producer surplus decreases outweigh consumer gains. Social gains from innovation that reduces cellulosic emission are positive. However, both corn and cellulosic producers are worse off. With cleaner cellulosic ethanol, producers receive a smaller implicit subsidy and less ethanol is required to meet the LCFS standard. In this case, the LCFS provides no private incentive for reducing cellulosic carbon intensity.

\section{Discussion}

There are a number of options for reducing greenhouse gas emissions from transportation fuels. If substitution towards ethanol is a major outcome of US policy, then a number of additional social costs beyond carbon merit consideration. Intuitively, polices that result in larger shifts in ethanol production will yield larger land-use and indirect emissions effects. Here, we show these effects can be quite large. For example, costs related to erosion and habitat loss are $\$ 277$ to $\$ 693$ million larger under the RFS compared to CAT. Similarly, costs from uncontrolled emissions can be large. For relatively small errors in emissions intensities, 10 percentage points in our example, costs due to uncontrolled emissions are nearly $\$ 150$ million greater under the LCFS compared to CAT. ${ }^{45}$

Proponents of transportation carbon policies often use innovation incentives as justification for these policies. We investigate gains from developing cellulosic ethanol, reducing costs and lowering fuel emissions intensities. Across the policies, social gains from the different types of innovation are in general positive. However, social gains are negative for developing cellulosic ethanol under subsidies and for reducing corn ethanol emissions under the LCFS. Private incentives for innovation under the alternatives to CAT can be too large or too small. In some cases, these policies lead to perverse incentives. Under the RFS, innovation the lowers cellulosic costs decreases cellulosic profits. Similarly, under the LCFS innovation that reduces cellulosic emissions decreases producer profits.

\footnotetext{
${ }^{45}$ As discussed previously, 10 percentage points is well-within the range of uncertainly for estimates of corn ethanol emissions rates.
} 
Overall, there are many challenges to policies such as the RFS, LCFS or ethanol subsidies. While several authors have highlighted desirable features of these approaches in a second-best setting (de Gorter and Just, 2010; Holland, 2012; Lapan and Moschini, 2012), a combination of first-best instruments would have lower efficiency costs. In terms of carbon abatement, there is growing evidence that the alternatives to CAT are quite costly ${ }_{46}^{46}$ Given the additional costs we estimate here, one must further question the wisdom of policies such as the RFS, LCFS and subsidies.

\footnotetext{
${ }^{46}$ For example, Holland et al. $(2013)$ find average abatement costs of carbon are 2.5 to 4 times higher under the RFS, LCFS and subsidies compared with CAT.
} 


\section{References}

Aden, A., M. Ruth, K. Ibsen, J. Jechura, K. Neeves, J. Sheehan, B. Wallace, L. Montague, and A. Slayton. 2002. "Lignocellulosic biomass to ethanol process design and economics utilizing co-current dilute acid prehydrolysis and enzymatic hydrolysis for corn stover." Tech. Rep. NREL/TP-510-32438, National Renewable Energy Laboratory.

Bento, Antonio M., Richard Klotz, and Joel Landry. 2012. "Are There Carbon Savings from US Biofuel Policies? The Critical Importance of Accounting for Leakage in Land and Fuel Markets." Working paper, Cornell University.

Butzen, S. and T. Hobbs. 2002. "Corn processing III. Wet milling." Crop Insights 12:1-6.

California Air Resources Board. 2009. "Proposed Regulation to Implement the Low Carbon Fuel Standard: Volume I." Tech. rep.

Chakravorty, Ujjayant, Marie-Hlne Hubert, Michel Moreaux, and Linda Nstbakken. 2013. "The Long Run Impact of Biofuels on Food Prices." Working Paper 3876, CESifo Group Munich.

Chen, Xiaoguang, Haixiao Huang, Madhu Khanna, and Hayri Onal. 2011. "Meeting the Mandate for Biofuels: Implications for Land Use, Food and Fuel Prices." Working Paper 16697, National Bureau of Economic Research.

Cui, Jingbo, Harvey Lapan, GianCarlo Moschini, and Joseph Cooper. 2011. "Welfare Impacts of Alternative Biofuel and Energy Policies." American Journal of Agricultural Economics 93 (5):1235-1256.

de Gorter, Harry and David R. Just. 2010. "The Social Costs and Benefits of Biofuels: The Intersection of Environmental, Energy and Agricultural Policy." Applied Economic Perspectives and Policy 32 (1):4-32.

Dumortier, Jerome, Dermot J. Hayes, Miguel Carriquiry, Fengxia Dong, Xiaodong Du, Amani Elobeid, Jacinto F. Fabiosa, and Simla Tokgoz. 2011. "Sensitivity of Carbon Emission Estimates from Indirect Land-Use Change." Applied Economic Perspectives and Policy 33 (3):428-448.

Fargione, Joseph, Jason Hill, David Tilman, Stephen Polasky, and Peter Hawthorne. 2009. "Land Clearing and the Biofuel Carbon Debt." Science 326 (5952):527-528. 
Fischer, Carolyn, Ian WH Parry, and William A Pizer. 2003. "Instrument choice for environmental protection when technological innovation is endogenous." Journal of Environmental Economics and Management 45 (3):523-545.

Gallagher, P. W., H. Brubaker, and H. Shapouri. 2005. "Plant size: capital cost relationships in the dry mill ethanol industry." Biomass and Bioenergy 28 (6):565-571.

Gallagher, P. W. and H. Shapouri. 2005. "USDA's 2002 Ethanol Cost-of-Production Survey." Tech. Rep. 841, U.S. Department of Agriculture, Office of the Chief Economist.

Gardner, Bruce. 2007. "Fuel Ethanol Subsidies and Farm Price Support." Journal of Agricultural and Food Industrial Organization 5 (4):1-20.

Graham, R. L., R. Nelson, J. Sheehan, R. D. Perlack, and L. L. Wright. 2007. "Current and Potential U.S. Corn Stover Supplies." Agronomy Journal 99 (1):1.

Greenstone, Michael, Elizabeth Kopits, and Ann Wolverton. 2011. "Estimating the Social Cost of Carbon for Use in U.S. Federal Rulemakings: A Summary and Interpretation." Working Paper 16913, National Bureau of Economic Research.

Hamelinck, Carlo N., Geertje van Hooijdonk, and Andr? P. C. Faaij. 2005. "Ethanol from lignocellulosic biomass: techno-economic performance in short-, middle- and long-term." Biomass and Bioenergy 28 (4):384-410.

Hansen, LeRoy. 2007. "Conservation Reserve Program: Environmental Benefits Update." Agricultural and Resource Economics Review 36 (2):267-280.

Hertel, Thomas W, Alla A Golub, Andrew D Jones, Michael O'Hare, Richard J Plevin, and Daniel M Kammen. 2010. "Effects of US maize ethanol on global land use and greenhouse gas emissions: estimating market-mediated responses." BioScience 60 (3):223-231.

Holland, Stephen P. 2012. "Emissions taxes versus intensity standards: Second-best environmental policies with incomplete regulation." Journal of Environmental Economics and Management 63 (3):375 - 387.

Holland, Stephen P., Jonathan E. Hughes, and Christopher R. Knittel. 2009. "Greenhouse Gas Reductions under Low Carbon Fuel Standards?" American Economic Journal: Economic Policy 1 (1):106-46.

Holland, Stephen P., Jonathan E. Hughes, Christopher R. Knittel, and Nathan C. Parker. 2013. "Some Inconvenient Truths About Climate Change Policy: The Distributional Impacts of Transportation Policies." Working paper, University of Colorado. 
Jaffe, Adam B and Robert N Stavins. 1995. "Dynamic incentives of environmental regulations: The effects of alternative policy instruments on technology diffusion." Journal of environmental economics and management 29 (3):S43-S63.

Johnstone, Nick, Ivan Haščič, and David Popp. 2010. "Renewable energy policies and technological innovation: Evidence based on patent counts." Environmental and Resource Economics 45 (1):133-155.

Jung, Chulho, Kerry Krutilla, and Roy Boyd. 1996. "Incentives for advanced pollution abatement technology at the industry level: An evaluation of policy alternatives." Journal of environmental economics and management 30 (1):95-111.

Kalogo, Youssouf, Shiva Habibi, Heather L. MacLean, and Satish Joshi. 2007. "Environmental Implications of Municipal Solid Waste-Derived Ethanol." Environmental Science and Technology 41 (1):35-41.

Keeney, Roman and Thomas W. Hertel. 2009. "The Indirect Land Use Impacts of United States Biofuel Policies: The Importance of Acreage, Yield, and Bilateral Trade Responses." American Journal of Agricultural Economics 91 (4):895-909.

Khanna, Madhu, Amy W. Ando, and Farzad Taheripour. 2008. "Welfare Effects and Unintended Consequences of Ethanol Subsidies." Applied Economic Perspectives and Policy $30(3): 411-421$.

Lapan, Harvey and GianCarlo Moschini. 2012. "Second-best biofuel policies and the welfare effects of quantity mandates and subsidies." Journal of Environmental Economics and Management $63(2): 224-241$.

Lubowski, Ruben N., Marlow Vesterby, Shawn Bucholtz, Alba Baez, and Michael J. Roberts. 2006. "Major Uses of Land in the United States, 2002." Tech. rep., U.S. Department of Agriculture, Economic Research Service.

McAloon, A., F. Taylor, W. Yee, K. Ibsen, and R. Wooley. 2000. "Determining the cost of producing ethanol from corn starch and lignocellulosic feedstocks." Tech. Rep. NREL/TP580-28893, National Renewable Energy Laboratory.

Milliman, Scott R and Raymond Prince. 1989. "Firm incentives to promote technological change in pollution control." Journal of Environmental economics and Management $17(3): 247-265$. 
Montero, Juan-Pablo. 2002. "Permits, standards, and technology innovation." Journal of Environmental Economics and Management 44 (1):23-44.

National Agricultural Statistics Service. 2009. "2007 Census of Agriculture.” URL http: //www.agcensus.usda.gov/Publications/2007/index.php. Accessed February 1, 2009.

Nelson, Richard. 2010. "National Biomass Resource Assessment and Supply Analysis."

Parker, Nathan C. 2011. Modeling Future Biofuel Supply Chains using Spatially Explicit Infrastructure Optimization. Ph.D. thesis, University of California, Davis.

— 2012. "Spatially Explicit Projection of Biofuel Supply for Meeting Renewable Fuel Standard." Journal of the Transportation Research Board (2287):72-79.

Renewable Fuels Association. 2009. "Biorefinery Locations." URL http://www. ethanolrfa.org/bio-refinery-locations/. Accessed December 3, 2009.

Roberts, Michael J. and Wolfram Schlenker. 2013. "Identifying Supply and Demand Elasticities of Agricultural Commodities: Implications for the US Ethanol Mandate." American Economic Review forthcoming.

Searchinger, Timothy, Ralph Heimlich, R. A. Houghton, Fengxia Dong, Amani Elobeid, Jacinto Fabiosa, Simla Tokgoz, Dermot Hayes, and Tun-Hsiang Yu. 2008. "Use of U.S. Croplands for Biofuels Increases Greenhouse Gases Through Emissions From Land-Use Change." Science 319 (5900):1238-1240.

Simmons, P., N. Goldstein, S. Kaufman, N. Themelis, and J. Thompson Jr. 2006. "The State of Garbage in America." BioCycle 47 (3):26-43.

Spatari, Sabrina, Yimin Zhang, and Heather L. MacLean. 2007. "Life Cycle Assessment of Switchgrass- and Corn Stover-Derived Ethanol-Fueled Automobiles." Environmental Science and Technology 39 (24):9750-9758.

State of California. 2010. "Low Carbon Fuel Standard." In California Code of Regulations, Title 17, Subchapter 10, Article 4, Subarticle \%.

United States Department of Agriculture. 2010. "Office of the Chief Economist, World Agricultural Outlook Board, USDA Agricultural Projections to 2019." Tech. Rep. OCE2010-1.

U.S. Congress. 2007. "Energy Independence and Security Act, H.R. 6." In Public Law No: $110-140$. 
U.S. Environmental Protection Agency. 2007. “2006 MSW Characterization Report.” URL http://www.epa.gov/osw/nonhaz/municipal/pubs/06data.pdf. Accessed December 1, 2009.

. 2010. "Renewable Fuel Standard Program (RFS2) Regulatory Impact Analysis." Tech. rep.

Wooley, R., M. Ruth, J. Sheehan, K. Ibsen, H. Majdeski, and A. Galvez. 1999. "Lignocellulosic biomass to ethanol process design and economics utilizing co-current dilute acid prehydrolysis and enzymatic hydrolysis current and futuristic scenarios." Tech. rep., National Renewable Energy Laboratory.

Wullschleger, E. B., E. B. Davis, M. E. Borsuk, C. A. Gunderson, and L. R. Lynd. 2010. "Biomass Production in Switchgrass across the United States: Database Description and Determinants of Yield." Agronomy Journal 102:1158-1168.

Zhang, Yimin, Satish Joshi, and Heather L. MacLean. 2010. "Can ethanol alone meet Californias low carbon fuel standard? An evaluation of feedstock and conversion alternatives." Environmental Research Letters (5):1-14.

Zilberman, David, Gal Hochman, Deepak Rajagopal, Steve Sexton, and Govinda Timilsina. 2013. "The Impact of Biofuels on Commodity Food Prices: Assessment of Findings." American Journal of Agricultural Economics 95 (2):275-281. 


\section{$\begin{array}{ll}7 & \text { Figures }\end{array}$}

Figure 1: Supply curves for corn and cellulosic ethanol fuels.

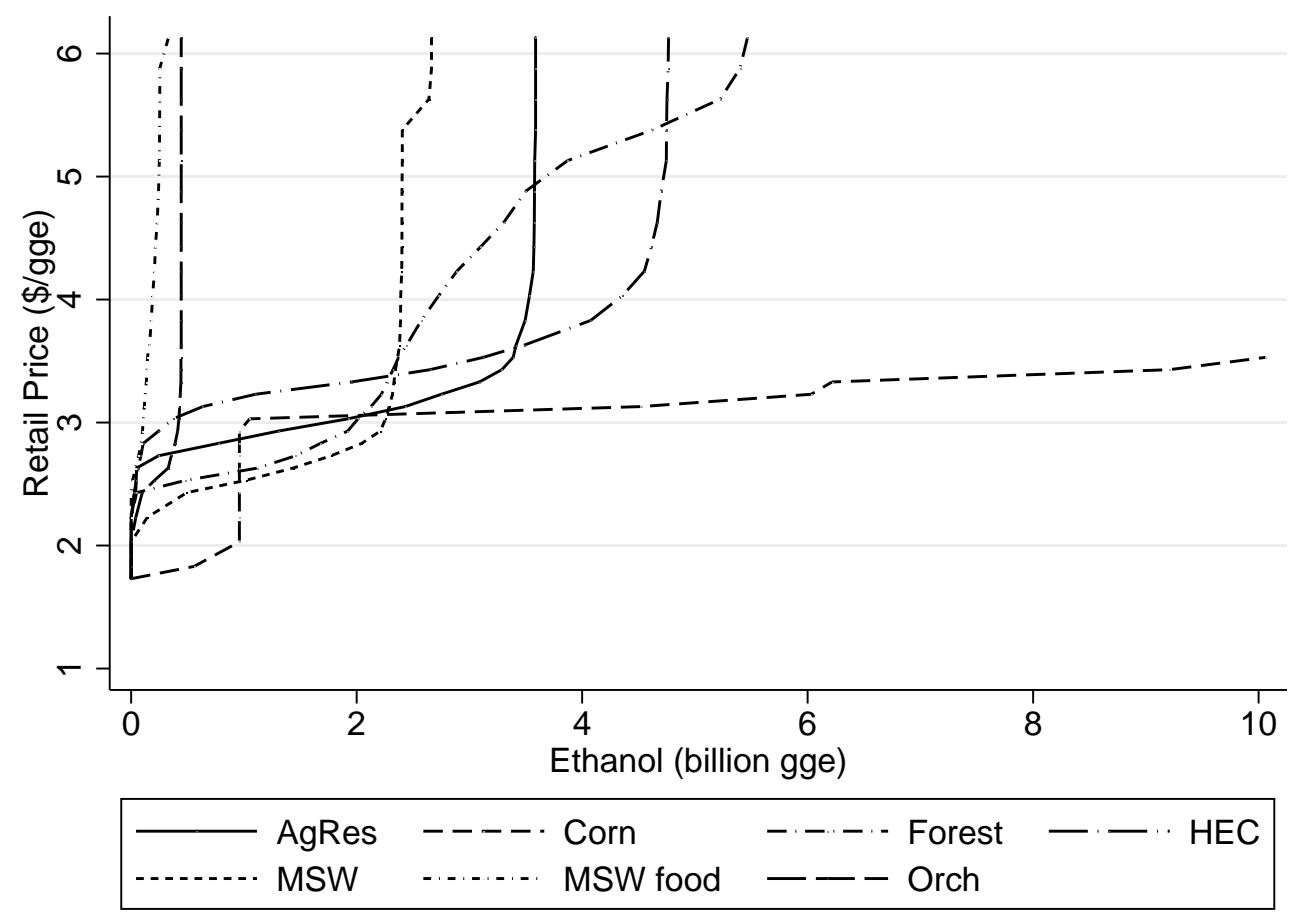


Figure 2: Marginal abatement cost curves and emissions reduction mechanisms for CAT and LCFS systems.
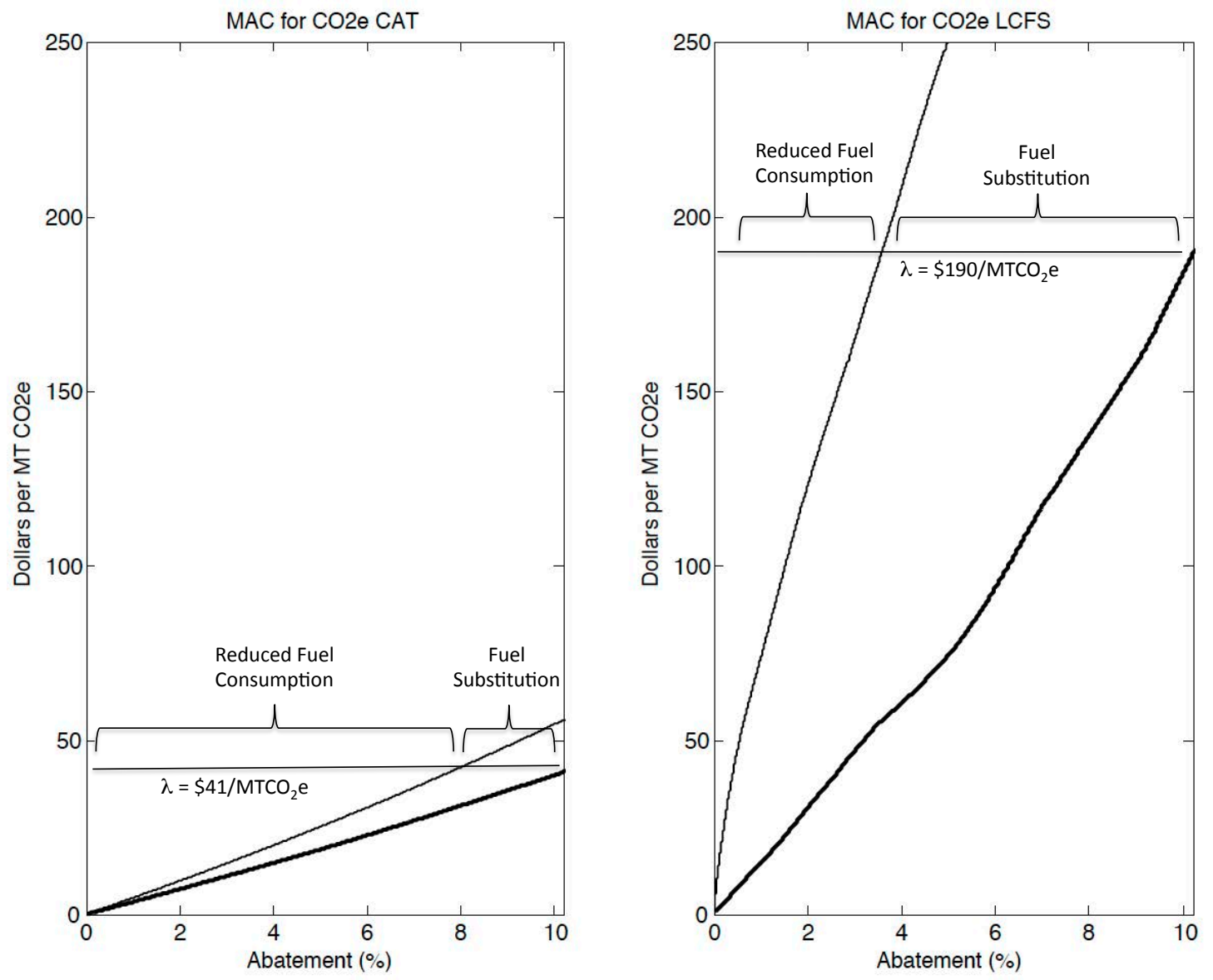

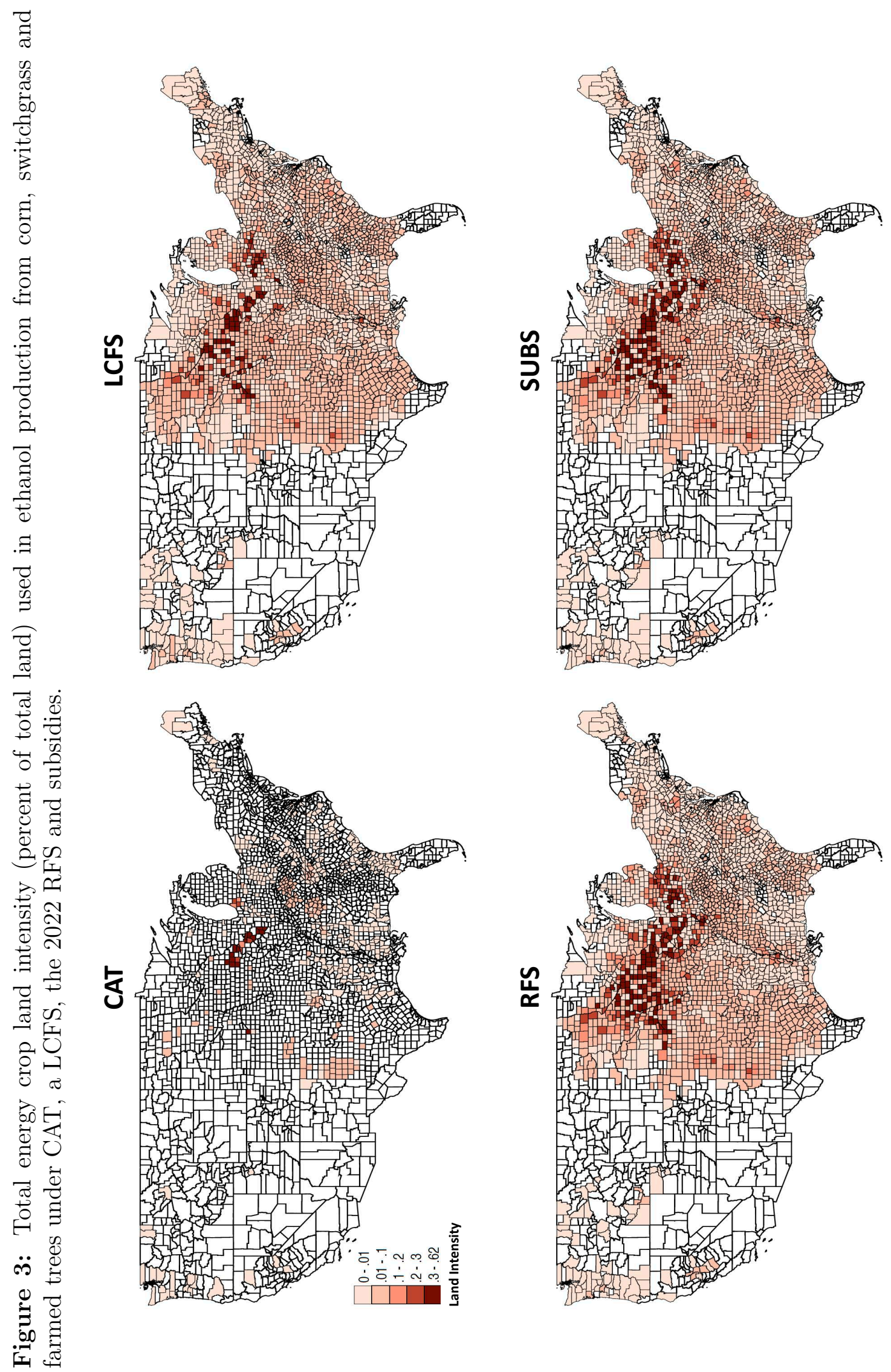

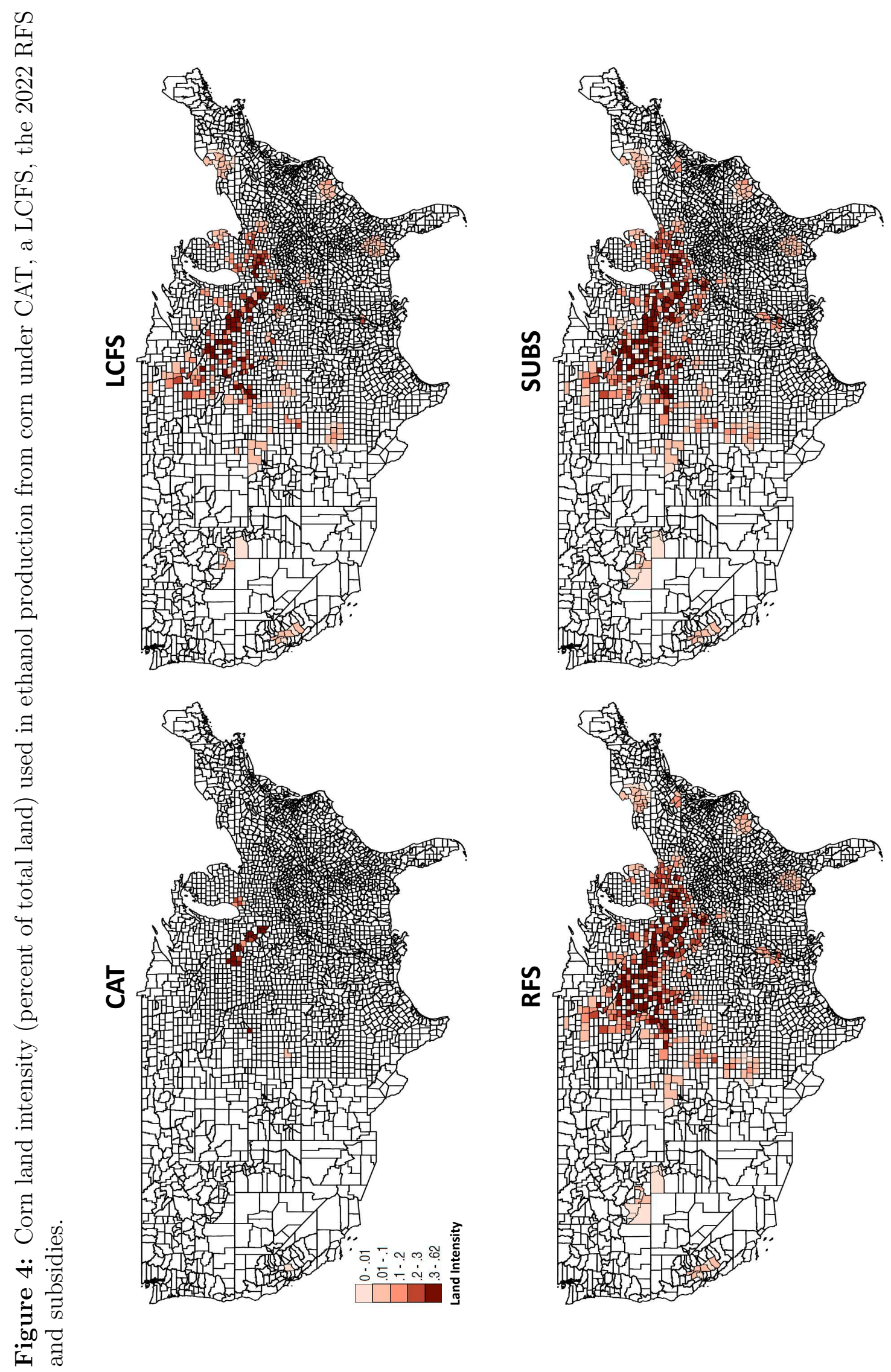


\section{Tables}

Table 1: Lifecycle GHG emission estimates for corn and cellulosic ethanol pathways.

\begin{tabular}{|c|c|c|c|c|c|}
\hline & CARB (2009) & EPA (2010) & Zhang et al. (2010) & Kalogo et al. (2007) & Spatari et al. (2005) \\
\hline Corn & 0.91 to 1.04 & 0.79 & 1.04 & & \\
\hline Herb. Energy Crops & & -0.10 & & & 0.24 \\
\hline \multicolumn{6}{|l|}{ Waste Biomass } \\
\hline Ag. Residues & & -0.29 & -0.09 to 0.16 & & 0.16 \\
\hline \multicolumn{6}{|c|}{ Orchard and Vineyard } \\
\hline Forest & 0.02 to 0.22 & & -0.06 to 0.19 & & \\
\hline Muni. Solid Waste & & & 0.042 & 0.16 to 0.35 & \\
\hline
\end{tabular}


Table 2: Fuel prices, quantities and emissions under BAU, RFS, LCFS, CAT and subsidies.

\begin{tabular}{|c|c|c|c|c|c|}
\hline & BAU & RFS & LCFS & CAT & SUBS. \\
\hline Fuel Price (\$/gge) & $\$ 2.75$ & $\$ 2.94$ & $\$ 2.96$ & $\$ 3.23$ & $\$ 2.75$ \\
\hline Fuel Quantity (bn. gge) & 140.0 & -4.7 & -5.0 & -10.9 & -0.0 \\
\hline Ethanol Quantity (bn. gge) & 5.2 & +18.5 & +14.9 & +3.8 & +18.2 \\
\hline Corn Ethanol & 0.96 & +8.9 & +4.6 & +0.0 & +8.3 \\
\hline Herb. Energy Crops & 0.09 & +4.3 & +4.5 & +0.5 & +4.5 \\
\hline Waste Feedstocks & 4.11 & +5.3 & +5.8 & +3.3 & +5.5 \\
\hline Volumetric Ethanol Blend Ratio & E6 & E24 & E21 & E10 & E23 \\
\hline Emissions $\left(\mathrm{MMTCO}_{2} \mathrm{e}\right)$ & 1619 & $-10.2 \%$ & $-10.2 \%$ & $-10.2 \%$ & $-6.9 \%$ \\
\hline
\end{tabular}

Table 3: Points on the distributions of county-level total energy crop intensity across policies.

\begin{tabular}{lrrrrr}
\hline & \multicolumn{1}{c}{ BAU } & \multicolumn{1}{c}{ RFS } & \multicolumn{1}{c}{ LCFS } & \multicolumn{1}{c}{ CAT } & \multicolumn{1}{c}{ SUBS } \\
\hline \hline Mean & $0.32 \%$ & $3.95 \%$ & $2.82 \%$ & $0.42 \%$ & $3.84 \%$ \\
Minimum & $0 \%$ & $0 \%$ & $0 \%$ & $0 \%$ & $0 \%$ \\
25th Percentile & $0 \%$ & $0.41 \%$ & $0.53 \%$ & $0 \%$ & $0.48 \%$ \\
Median & $0 \%$ & $0.94 \%$ & $1.05 \%$ & $0 \%$ & $1.03 \%$ \\
75th Percentile & $0 \%$ & $1.97 \%$ & $1.84 \%$ & $0 \%$ & $2.01 \%$ \\
90th Percentile & $0 \%$ & $12.55 \%$ & $3.73 \%$ & $0.11 \%$ & $9.31 \%$ \\
95th Percentile & $0 \%$ & $26.24 \%$ & $14.35 \%$ & $0.99 \%$ & $25.39 \%$ \\
Maximum & $50.97 \%$ & $61.97 \%$ & $60.19 \%$ & $50.97 \%$ & $61.97 \%$ \\
\hline
\end{tabular}

Notes: Distributions are conditional on energy-crop counties which are the 2,670 counties that would produce some energy crops in our model at a sufficiently high fuel price of $\$ 6.13$ per gge. 
Table 4: Land-use changes under alternate policies.

\begin{tabular}{lrrrrr}
\hline \hline & & & & & \\
& BAU & RFS & LCFS & CAT & SUBS. \\
\hline Corn Acres & 2,892 & $+27,708$ & $+14,708$ & +8 & $+25,708$ \\
Herb. Energy Crop Acres & 225 & $+10,075$ & $+10,675$ & $+1,044$ & $+10,475$ \\
Farmed Trees Acres & 4 & $+1,208$ & $+2,176$ & +106 & $+1,557$ \\
& & & & & \\
\hline Total Acres (1000s of Acres) & 3,121 & $+38,991$ & $+27,559$ & $+1,158$ & $+37,739$ \\
\end{tabular}

Notes: For the RFS, LCFS, CAT and SUBS policies a " + " indicates an increase in acreage relative to BAU. Land areas are measured in 1000s of acres.

Table 5: Non-carbon land use costs for corn production under alternate policies.

\begin{tabular}{|c|c|c|c|c|}
\hline & RFS & LCFS & CAT & SUBS. \\
\hline \multicolumn{5}{|l|}{ Low Scenario ( $\$ 10$ per corn acre) } \\
\hline Land-Use Cost (\$ mil.) & $\$ 277.08$ & $\$ 147.08$ & $\$ 0.08$ & $\$ 257.08$ \\
\hline Land-Use Cost (\$/MTCO2e) & $\$ 1.68$ & $\$ 0.89$ & $<\$ 0.01$ & $\$ 2.31$ \\
\hline Percentage of Social Cost of Carbon & $6 \%$ & $3 \%$ & $0 \%$ & $9 \%$ \\
\hline \multicolumn{5}{|l|}{ High Scenario ( $\$ 25$ per corn acre) } \\
\hline Land-Use Cost (\$ mil.) & $\$ 692.69$ & $\$ 367.69$ & $\$ 0.20$ & $\$ 642.69$ \\
\hline Land-Use Cost (\$/MTCO2e) & $\$ 4.19$ & $\$ 2.22$ & $<\$ 0.01$ & $\$ 5.77$ \\
\hline Percentage of Social Cost of Carbon & $16 \%$ & $8 \%$ & $0 \%$ & $22 \%$ \\
\hline
\end{tabular}

Notes: Assuming a SCC of \$26.3 per ton per Greentone et. al. (2011) for 2020 with a $3 \%$ discount rate. 
Table 6: Uncontrolled emissions due to errors in estimating carbon intensity.

\begin{tabular}{lcccr}
\hline & RFS & LCFS & CAT & SUBS \\
\hline \hline Regulated Emissions $\left(\mathrm{MMTCO}_{2} \mathrm{e}\right)$ & 1454 & 1454 & 1454 & 1508 \\
True Emissions $\left(\mathrm{MMTCO}_{2} \mathrm{e}\right)$ & 1465 & 1460 & 1455 & 1519 \\
Uncontrolled as \% of stated reduction & $7.1 \%$ & $4.0 \%$ & $0.7 \%$ & $9.9 \%$ \\
Additional carbon damages (\$ mil.) & $\$ 307.76$ & $\$ 174.20$ & $\$ 29.96$ & $\$ 288.50$ \\
\hline Notes: "Regulated emissions" assumes regulators set the emissions intensity for corn ethanol to \\
$\sigma_{\text {reg. }}=0.80$. "True emissions" assumes corn emissions are actually $\sigma_{\text {act. }}=0.90$. The difference \\
between regulated and true emissions results in "uncontrolled emissions" above the level \\
targeted by the policy. Additional carbon damages of uncontrolled emissions are calculated \\
using the Interagency Working Group (2011) central estimate for the SCC in 2020 \\
of \$26/MTCO2e
\end{tabular}

Table 7: Incentives for development of cellulosic ethanol under alternate policies.

\begin{tabular}{|c|c|c|c|c|}
\hline & $\mathrm{BAU}$ & LCFS & CAT & SUBS \\
\hline$\Delta$ Social Surplus ( $\$$ bn.) & $\$ 0.91$ & $\$ 2.61$ & $\$ 4.38$ & $-\$ 4.43$ \\
\hline$\Delta \mathrm{CS}$ & $\$ 0.00$ & $\$ 67.08$ & $\$ 43.44$ & $\$ 0.00$ \\
\hline$\Delta \mathrm{PS}$ & $\$ 0.91$ & $-\$ 64.47$ & $\$ 3.24$ & $\$ 17.29$ \\
\hline$\Delta$ PS (Corn Ethanol) & $\$ 0.00$ & $-\$ 85.03$ & $-\$ 0.07$ & $\$ 0.00$ \\
\hline$\Delta$ PS (Cellulosic Ethanol) & $\$ 0.91$ & $\$ 20.56$ & $\$ 3.31$ & $\$ 17.29$ \\
\hline$\Delta$ Carbon Mkt. Rev. or Sub. Payments ( $\$$ bn.) & & & $-\$ 42.30$ & $\$ 21.72$ \\
\hline \multicolumn{5}{|l|}{ Fuel Price (\$/gge) } \\
\hline Without Innovation & $\$ 2.75$ & $\$ 3.48$ & $\$ 3.58$ & $\$ 2.75$ \\
\hline With Innovation & $\$ 2.75$ & $\$ 2.96$ & $\$ 3.23$ & $\$ 2.75$ \\
\hline \multicolumn{5}{|l|}{ Average Abatement Cost $\left(\$ / \mathrm{MTCO}_{2} \mathrm{e}\right)$} \\
\hline Without Innovation & & $\$ 58.87$ & $\$ 40.54$ & $\$ 194.45$ \\
\hline With Innovation & & $\$ 48.58$ & $\$ 19.52$ & $\$ 82.30$ \\
\hline
\end{tabular}

Notes: The change in surplus is the additional surplus from including our six types of cellulosic ethanol (With Innovation) relative to the counterfactual which excludes cellulosic ethanol

(Without Innovation). Surplus is calculated as PS + CS + Carbon Market Revenue - Subsidy Payments. 
Table 8: Incentives for reducing cellulosic ethanol costs under alternate policies.

\begin{tabular}{|c|c|c|c|c|c|}
\hline & BAU & RFS & LCFS & CAT & SUBS \\
\hline$\Delta$ Social Surplus (\$ bn.) & $\$ 0.81$ & $\$ 7.03$ & $\$ 5.75$ & $\$ 2.58$ & $\$ 3.91$ \\
\hline$\Delta \mathrm{CS}$ & $\$ 0.00$ & $\$ 10.00$ & $\$ 2.97$ & $\$ 16.71$ & $\$ 0.00$ \\
\hline$\Delta \mathrm{PS}$ & $\$ 0.81$ & $-\$ 2.97$ & $\$ 2.79$ & $\$ 1.89$ & $\$ 6.39$ \\
\hline$\Delta$ PS (Corn Ethanol) & $\$ 0.00$ & $\$ 0.00$ & $-\$ 0.40$ & $-\$ 0.03$ & $\$ 0.00$ \\
\hline$\Delta$ PS (Cellulosic Ethanol) & $\$ 0.81$ & $-\$ 2.97$ & $\$ 3.18$ & $\$ 1.91$ & $\$ 6.39$ \\
\hline$\Delta$ Carbon Mkt. Rev. or Sub. Payments ( $\$$ bn.) & & & & $-\$ 16.02$ & $\$ 2.48$ \\
\hline \multicolumn{6}{|l|}{ Fuel Price (\$/gge) } \\
\hline Without Innovation & $\$ 2.75$ & $\$ 3.02$ & $\$ 2.98$ & $\$ 3.37$ & $\$ 2.75$ \\
\hline With Innovation & $\$ 2.75$ & $\$ 2.94$ & $\$ 2.96$ & $\$ 3.23$ & $\$ 2.75$ \\
\hline \multicolumn{6}{|l|}{ Average Abatement Cost $\left(\$ / \mathrm{MTCO}_{2} \mathrm{e}\right)$} \\
\hline Without Innovation & & $\$ 72.07$ & $\$ 78.52$ & $\$ 30.26$ & $\$ 93.99$ \\
\hline With Innovation & & $\$ 57.90$ & $\$ 48.58$ & $\$ 19.52$ & $\$ 82.30$ \\
\hline
\end{tabular}

Notes: The change in surplus is the additional surplus from technology that reduces costs of cellulosic ethanol (With Innovation) to our base cost levels relative to the counterfactual where cellulosic ethanol costs are 20 percent higher (Without Innovation). Surplus is calculated as PS + CS + Carbon Market Revenue - Subsidy Payments. 
Table 9: Incentives for reducing ethanol emission intensities under alternate policies.

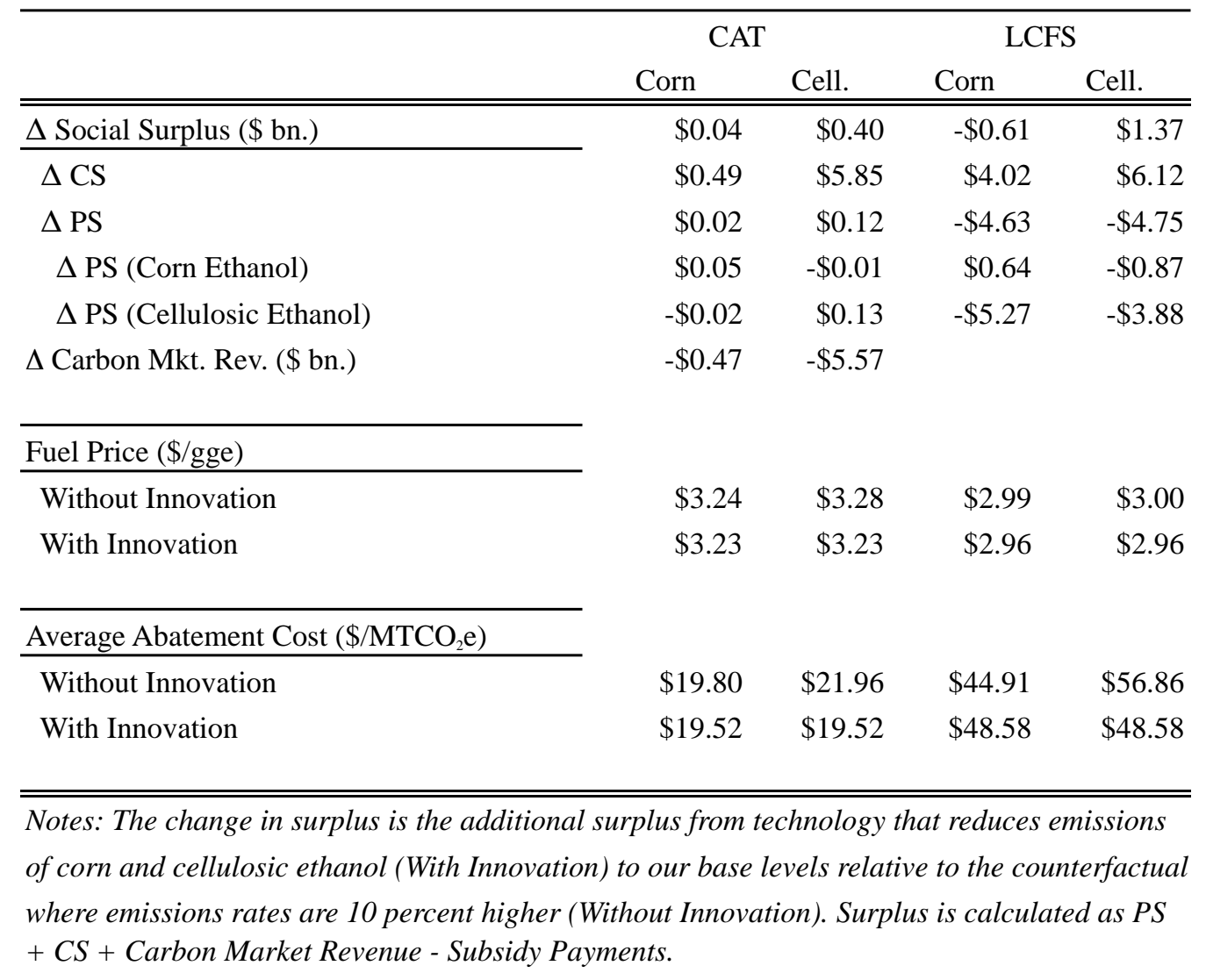




\section{Appendices}

\section{A Resource consumption}

For each of the ethanol feedstocks in our model, Appendix Table1 1 reports the total quantity of biomass consumed under each policy. Changes in total biomass consumption range from approximately 79 million tons per year under CAT, to approximately 352 million tons per year under subsidies. These changes are substantial compared with the approximately 85 million tons per year consumed under BAU. Corn is by far the largest input to ethanol production under the RFS and subsidy policies. Under the RFS, an additional 135 million tons, or 5.4 billion bushels, are consumed annually. To put this number in perspective, this exceeds the current combined output of Iowa, Illinois, and Indiana. ${ }^{47}$

In terms of cellulosic feedstocks, herbaceous energy crops represent a large share of feedstock consumption under the RFS, LCFS, and subsidies policies. Agricultural residues, municipal waste and other waste feedstocks contribute between 143 and 213 million tons annually to ethanol production. However, under the RFS and subsidy policies, wastes represent less than half of total biomass consumed. Under the LCFS, the waste share of total tons is approximately 55 percent. Under CAT, approximately 87 percent of total tons come from waste. This suggests that while wastes are important biofuel feedstocks, the alternatives to CAT will also require high levels of energy crop production.

\section{B Robustness}

We investigate the robustness of our results along several dimensions. Specifically, we explore our assumptions about baseline fuel prices, emissions intensities and demand elasticities. In addition, we allow corn prices and therefore our corn ethanol supply curve to vary based on changes in corn consumption. We begin with the fuel price scenarios.

Our preferred results assume a baseline fuel price of $\$ 2.75$ per gallon. Given our assumption of perfectly elastic gasoline supply, higher (lower) baseline fuel prices imply more (less) ethanol is produced under BAU. Therefore, land-use changes under each policy also depend on this assumption. We rerun our simulations for two alternate baseline prices, $\$ 2.25$ per

\footnotetext{
${ }^{47}$ See http://www.ers.usda.gov/data-products/feed-grains-database/ for detailed data on US corn production.
} 
gge and $\$ 3.25$ per gge. Results for these cases are presented alongside our preferred results in Appendix Table 2. At the lower price, less switchgrass is produced resulting in fewer acres devoted to energy crop production under BAU. At the higher price, substantially more acreage is devoted to corn production under BAU. Higher prices move production onto the elastic portion of the corn ethanol supply curve resulting in a large increase in land use, compared with our main results. That said, looking across the policies, the RFS, LCFS and SUBS each still result in large additional increases in acreage. Under CAT, though the change in acreage is higher at $\$ 3.25$ baseline price, the increase relative to BAU is still quite small compared to the other policies.

Next, we investigate the robustness of our results to different emissions intensities. Appendix Table 3 shows our preferred emissions parameters as well as several alternate scenarios. The "High-Indirect Land Use" scenario assumes the indirect emissions of expanding energy crop production are larger than expected. We increase the corn and herbaceous energy crop intensities to 1.00 and 0.40, respectively. The "Waste-Zero" scenario assumes ethanol from waste biomass results in zero net carbon emissions. Finally, the "Existing Corn" scenario assumes new corn ethanol plants have emissions profiles similar to current technology plants 48 We use 0.90 for corn ethanol, but leave the other parameters at their base levels. We re-run our simulation model under each of these scenarios. Results of this exercise are presented in Appendix Table 4. Changing emissions parameters has no effect on land use in the BAU case or under the RFS or SUBS because these policies don't explicitly consider the carbon emissions of fuels 49 Under the LCFS and CAT, scenarios with higher corn emissions make corn ethanol a less attractive substitute for gasoline. This results in smaller land use shifts under the LCFS relative to BAU. However, land-use changes under CAT are still substantially less than under the LCFS.

Appendix Table 5 presents simulation results for different price elasticities of gasoline demand. Our preferred simulations use a price elasticity of -0.50 . Here, we simulate less elastic and more elastic demand assuming elasticities of -0.30 and -0.70 . The land-use change estimates are very similar to our base results. Because we update the RFS ratios to meet the overall quantity mandates, the RFS estimates are identical across the three elasticity scenarios. Under subsidies, our assumption of perfectly elastic gasoline implies fuel prices do not change, and varying the demand elasticity does not affect fuel consumption. For the LCFS and CAT policies, more elastic demand means less ethanol is required to meet a given

\footnotetext{
${ }^{48}$ I.e. there is no additional innovation in emissions for corn ethanol technology.

${ }^{49} \mathrm{We}$ assume that changing the emissions intensities of fuels doesn't change the classifications of fuels, i.e. advanced versus cellulosic, under the RFS.
} 
carbon reduction 50 This reduces land-use changes relative to BAU, though, this effect is quite small.

Our corn ethanol supply curves take corn price as fixed. Corn represents a substantial fraction of the cost of producing corn ethanol, in our simulations approximately $\$ 2.00$ per gasoline gallon equivalent. We set corn prices under the 2022 RFS to $\$ 3.64$ per bushel, consistent with production of 10 billion gge per year of corn ethanol (United States Department of Agriculture, 2010). This approach is reasonable for evaluating the land-use effects of the RFS. However, substantially less corn ethanol is produced under BAU and CAT, which may lower corn prices. To gauge the sensitivity of our results to this assumption, we use an elasticity of corn prices with respect to corn consumption of 0.12 (Gardner, 2007) to adjust our supply curve for corn price effects. We then re-run our simulation model using the adjusted supply curve. Appendix Table 6 shows the results of this exercise. Lower marginal costs for modest levels of corn ethanol production (compared with the RFS) mean that more corn acreage is used for the LCFS, CAT and SUBS, relative to our base case. However, these effects are again small and the relative differences in land-use across policies remains large.

\section{Environmental costs per acre of cropland}

Land-use changes have important implications for indirect carbon emissions, food prices, run-off, erosion and habitat loss. Because different transportation carbon policies are likely to result in vastly different land-use changes, we consider these costs an important part of any policy evaluation. We incorporate indirect carbon emissions directly in our baseline emissions intensity parameters. However, increased ethanol production may result in other land-use related externalities such as erosion or habitat loss.

One of the potential benefits of herbaceous energy crops, such as switchgrass, are the low environmental costs of cultivation. Our supply curves assume switchgrass is grown on marginal agricultural lands without irrigation or application of chemical fertilizers. We imagine that these farming practices do not substantially increase, and potentially reduce, erosion. Furthermore, we assume that when land is converted to switchgrass farming, these fields offer similar wildlife habitat to the fallow land being replaced. Under these circumstances, we conservatively estimate the environmental costs of additional lands devoted to herbaceous energy crop production as zero. Similarly, we assume farmed trees do not result in additional environmental costs per acre.

\footnotetext{
${ }^{50}$ Because a greater share of emissions reductions come from reduced fuel consumption.
} 
Cultivated crops such as corn on the other hand may have more serious environmental costs. Land used for increased corn production comes from a combination of existing agricultural land previously used for other cultivated crops, and new lands being brought into production. To a first approximation, we assume the environmental costs of corn and other cultivated crops are similar. Therefore, we ignore the fraction of land coming from crop substitution. To model new lands, we assume any additional acres come from the Conservation Reserve Program (CRP). Hansen (2007), studies the benefits of CRP in terms of reduced erosion and habitat preservation. He estimates an annual benefit of approximately $\$ 1.3$ billion for the approximately 36 million acres in CRP for an average annual benefit of approximately $\$ 36$ per acre per year. Benefits vary substantially by region. In the nation's corn belt, Hansen (2007) estimates CRP benefits of over $\$ 80$ per acre. We use $\$ 36$ per acre and $\$ 80$ per acre as lower and upper bounds on the range of potential costs.

To estimate the fraction of new acres per additional acre of corn produced we refer to previous work on land use changes from biofuel production. Searchinger et al. (2008) model global land-use changes under the Federal RFS. The authors find that a 56 billion liter (15 billion gallon) increase in U.S. corn ethanol production, increases corn acreage by 7.9 million hectares (19.5 million acres). Total cropland increases by 2.2 million hectares (29\%). Hertel et al. (2010) find increased ethanol production requires an additional 6 million hectares (14.8 million acres) of coarse grain production with an increase of 1.6 million hectares $(27 \%)$ overall. Therefore, we assume that each additional corn acre increases total US agricultural acreage by 0.3 acres. Based on these assumptions, we use a range of environmental costs from land-use change between $\$ 10$ and $\$ 25$ per additional acre of corn production.

\section{Innovation and a range of cellulosic cost reductions}

Appendix Table 7 shows gains from innovation under a range of reductions in cellulosic ethanol costs. Results are shown for the LCFS, CAT and subsidies. As discussed in Section 5.4. social benefits from innovation under the LCFS are larger for small cost reductions compared with R\&D that leads to the development of cellulosic ethanol. The intuition for this result is illustrated in the top half of Appendix Table 7. Consumers gain from innovation that lowers cellulosic costs or leads to the introduction of cellulosic ethanol. Moving from left to right in Appendix Table 7, the gains grow larger with the magnitude of the cost reduction. For relatively small cost reductions, 20\%, 50\%, 75\%, and 150\%, the gains from innovation to cellulosic producers outweigh loses to corn ethanol producers. However, with more innovation, loses to corn ethanol producers outweigh gains to cellulosic producers and 
eventually reduce overall social surplus gains. Overall, incentives for innovation under the LCFS, vary substantially depending on how much R\&D lowers costs. However, producer incentives are always smaller than social benefits from innovation.

Under CAT, without innovation that leads to large reductions in costs, no cellulosic ethanol is produced. We see this in Appendix Table 7 where no cellulosic ethanol is produced in any counterfactual where costs are 75 percent greater than our base estimates. In each of these cases, the gains from innovation are the same because cellulosic production goes from zero to the base level of approximately 8 billion gge per year. Overall, innovation in cellulosic costs lowers energy prices, increases consumer surplus and cellulosic producer surplus while modestly decreasing corn ethanol producer surplus.

Finally, with subsidies social gains from innovation are positive when cost reductions are small. For larger cost reductions, or for the development of cellulosic ethanol, innovation leads to substantial increases in subsidy payments which outweigh increases in producer surplus. Intuitively, innovation generates deadweight loss when the marginal private costs of production exceed marginal private benefits. When costs are high, these loses are small. Innovation lowers these costs and increases the inefficiency of subsidies. Under subsidies, no cellulosic ethanol is produced in any counterfactual where cellulosic costs are 150 percent greater than our base estimates. 


\section{Appendix tables}

Table 1: Biomass feedstock consumption under BAU, RFS, LCFS, CAT and subsidies.

\begin{tabular}{lrrrrr}
\hline \hline & BAU & RFS & LCFS & CAT & SUBS. \\
\hline Corn & $16,400+134,600$ & $+70,200$ & +0 & $+125,600$ \\
Herbaceous Energy Crops & 1,771 & $+85,429$ & $+89,029$ & $+9,829$ & $+88,129$ \\
Agricultural Residues & 6,745 & $+61,855$ & $+62,355$ & $+40,755$ & $+62,255$ \\
Farmed Trees & 25,400 & $+21,700$ & $+29,000$ & $+10,600$ & $+24,300$ \\
Municipal Solid Waste & 32,900 & $+44,400$ & $+44,600$ & $+16,100$ & $+44,500$ \\
Municipal Food Waste & 1,392 & $+2,475$ & $+3,019$ & +919 & $+2,713$ \\
Orchard and Vineyard Waste & 6,478 & $+1,450$ & $+1,450$ & $+1,211$ & $+1,450$ \\
\hline Total Biomass Consumed (1000s of Tons) & $84,608+351,909+299,653$ & $+79,414$ & $+348,948$ \\
\hline \hline
\end{tabular}

Notes: For the RFS, LCFS, CAT and SUBS policies a "+" indicates an increase in biomass consumption relative to BAU. Biomass quantities are measured in 1000s of tons. 
Table 2: Land-use changes under different baseline fuel prices.

\begin{tabular}{|c|c|c|c|c|c|}
\hline & BAU & RFS & LCFS & CAT & SUBS \\
\hline \multicolumn{6}{|l|}{ Corn (1000s of Acres) } \\
\hline Low Fuel Price: $\$ 2.25$ & 2,892 & $+27,708$ & +78 & +0 & +56 \\
\hline Base Case: $\$ 2.75$ & 2,892 & $+27,708$ & $+14,708$ & +8 & $+25,708$ \\
\hline High Fuel Price: $\$ 3.25$ & 19,100 & $+11,500$ & $+10,700$ & +200 & $+12,200$ \\
\hline \multicolumn{6}{|l|}{ HEC (1000s of Acres) } \\
\hline Low Fuel Price: $\$ 2.25$ & 5 & $+10,295$ & $+11,195$ & +222 & $+8,764$ \\
\hline Base Case: $\$ 2.75$ & 225 & $+10,075$ & $+10,675$ & $+1,044$ & $+10,475$ \\
\hline High Fuel Price: $\$ 3.25$ & 2,687 & $+7,613$ & $+7,613$ & $+2,968$ & $+8,513$ \\
\hline \multicolumn{6}{|l|}{ Farmed Trees (1000s of Acres) } \\
\hline Low Fuel Price: $\$ 2.25$ & 0 & $+1,212$ & $+3,285$ & +6 & +676 \\
\hline Base Case: $\$ 2.75$ & 4 & $+1,208$ & $+2,176$ & +106 & $+1,557$ \\
\hline High Fuel Price: $\$ 3.25$ & 170 & $+1,042$ & $+1,128$ & +128 & $+2,460$ \\
\hline \multicolumn{6}{|l|}{ Total (1000s of Acres) } \\
\hline Low Fuel Price: $\$ 2.25$ & 2,897 & $+39,215$ & $+14,558$ & +227 & $+9,496$ \\
\hline Base Case: $\$ 2.75$ & 3,121 & $+38,991$ & $+27,559$ & $+1,158$ & $+37,739$ \\
\hline High Fuel Price: $\$ 3.25$ & 21,957 & $+20,154$ & $+19,440$ & $+3,296$ & $+23,173$ \\
\hline
\end{tabular}

Notes: For the RFS, LCFS, CAT and SUBS policies a "+" indicates an increase in acreage relative to BAU. Land areas are measured in 1000s of acres. 
Table 3: Baseline emissions intensities and emissions scenario parameters.

\begin{tabular}{lcccc}
\hline \hline & & & & \\
& Base Case & $\begin{array}{c}\text { High Indirect } \\
\text { Land use }\end{array}$ & $\begin{array}{l}\text { Waste Zero Existing Corn } \\
\text { Emissions }\end{array}$ & \\
\hline Corn & 0.80 & 1.00 & 0.80 & 0.90 \\
Herb. Energy Crops & 0.25 & 0.40 & 0.25 & 0.25 \\
Waste Biomass & 0.20 & 0.20 & 0.00 & 0.20 \\
\hline \hline
\end{tabular}

Notes: Emission intensities are relative to gasoline.

Table 4: Land-use changes under different emission intensities.

\begin{tabular}{|c|c|c|c|c|c|}
\hline & $\mathrm{BAU}$ & RFS & LCFS & CAT & SUBS \\
\hline \multicolumn{6}{|l|}{ Corn (1000s of Acres) } \\
\hline Base Case & 2,892 & $+27,708$ & $+14,708$ & +8 & $+25,708$ \\
\hline High Indirect Land use & 2,892 & $+27,708$ & +0 & +0 & $+25,708$ \\
\hline Waste Zero Emissions & 2,892 & $+27,708$ & $+11,808$ & +8 & $+25,708$ \\
\hline Existing Corn & 2,892 & $+27,708$ & +174 & +0 & $+25,708$ \\
\hline \multicolumn{6}{|l|}{ HEC (1000s of Acres) } \\
\hline Base Case & 225 & $+10,075$ & $+10,675$ & $+1,044$ & $+10,475$ \\
\hline High Indirect Land use & 225 & $+10,075$ & $+10,075$ & +502 & $+10,475$ \\
\hline Waste Zero Emissions & 225 & $+10,075$ & $+10,375$ & $+1,037$ & $+10,475$ \\
\hline Existing Corn & 225 & $+10,075$ & $+10,775$ & +912 & $+10,475$ \\
\hline \multicolumn{6}{|l|}{ Farmed Trees (1000s of Acres) } \\
\hline Base Case & 4 & $+1,208$ & $+2,176$ & +106 & $+1,557$ \\
\hline High Indirect Land use & 4 & $+1,208$ & $+2,202$ & +76 & $+1,557$ \\
\hline Waste Zero Emissions & 4 & $+1,208$ & $+2,482$ & +156 & $+1,557$ \\
\hline Existing Corn & 4 & $+1,208$ & $+2,407$ & +94 & $+1,557$ \\
\hline \multicolumn{6}{|l|}{ Total (1000s of Acres) } \\
\hline Base Case & 3,121 & $+38,991$ & $+27,559$ & $+1,158$ & $+37,739$ \\
\hline High Indirect Land use & 3,121 & $+38,991$ & $+12,277$ & +578 & $+37,739$ \\
\hline Waste Zero Emissions & 3,121 & $+38,991$ & $+24,665$ & $+1,200$ & $+37,739$ \\
\hline Existing Corn & 3,121 & $+38,991$ & $+13,357$ & $+1,006$ & $+37,739$ \\
\hline
\end{tabular}

Notes: For the RFS, LCFS, CAT and SUBS policies a $"+"$ indicates an increase in acreage relative to BAU. Land areas are measured in 1000s of acres. 
Table 5: Land-use changes under different demand elasticities.

\begin{tabular}{|c|c|c|c|c|c|}
\hline & BAU & RFS & LCFS & CAT & SUBS \\
\hline \multicolumn{6}{|l|}{ Corn (1000s of Acres) } \\
\hline Less Elastic: Elast. $=-0.30$ & 2,892 & $+27,708$ & $+15,108$ & +21 & $+25,708$ \\
\hline Base Case: Elast. $=-0.50$ & 2,892 & $+27,708$ & $+14,708$ & +8 & $+25,708$ \\
\hline More Elastic: Elast. $=-0.70$ & 2,892 & $+27,708$ & $+14,408$ & +2 & $+25,708$ \\
\hline \multicolumn{6}{|l|}{ HEC (1000s of Acres) } \\
\hline Less Elastic: Elast. $=-0.30$ & 225 & $+10,075$ & $+10,675$ & $+1,955$ & $+10,475$ \\
\hline Base Case: Elast. $=-0.50$ & 225 & $+10,075$ & $+10,675$ & $+1,044$ & $+10,475$ \\
\hline More Elastic: Elast. $=-0.70$ & 225 & $+10,075$ & $+10,675$ & +792 & $+10,475$ \\
\hline \multicolumn{6}{|l|}{ Farmed Trees (1000s of Acres) } \\
\hline Less Elastic: Elast. $=-0.30$ & 4 & $+1,208$ & $+2,253$ & +164 & $+1,557$ \\
\hline Base Case: Elast. $=-0.50$ & 4 & $+1,208$ & $+2,176$ & +106 & $+1,557$ \\
\hline More Elastic: Elast. $=-0.70$ & 4 & $+1,208$ & $+2,131$ & +83 & $+1,557$ \\
\hline \multicolumn{6}{|l|}{ Total (1000s of Acres) } \\
\hline Less Elastic: Elast. $=-0.30$ & 3,121 & $+38,991$ & $+28,036$ & $+2,140$ & $+37,739$ \\
\hline Base Case: Elast. $=-0.50$ & 3,121 & $+38,991$ & $+27,559$ & $+1,158$ & $+37,739$ \\
\hline More Elastic: Elast. $=-0.70$ & 3,121 & $+38,991$ & $+27,213$ & +877 & $+37,739$ \\
\hline
\end{tabular}

Notes: For the RFS, LCFS, CAT and SUBS policies $a "+"$ indicates an increase in acreage relative to BAU. Land areas are measured in 1000s of acres. 
Table 6: Equilibrium outcomes under carbon policies incorporating corn price effects.

\begin{tabular}{|c|c|c|c|c|c|}
\hline & BAU & RFS & LCFS & CAT & SUBS \\
\hline \multicolumn{6}{|l|}{$\overline{\text { Corn (1000s of Acres) }}$} \\
\hline Base Case & 2,892 & $+27,708$ & $+14,708$ & +8 & $+25,708$ \\
\hline Endogenous Corn Prices & 3,018 & $+27,582$ & $+16,182$ & $+2,009$ & $+26,082$ \\
\hline \multicolumn{6}{|l|}{ HEC (1000s of Acres) } \\
\hline Base Case & 225 & $+10,075$ & $+10,675$ & $+1,044$ & $+10,475$ \\
\hline Endogenous Corn Prices & 225 & $+10,075$ & $+10,675$ & $+1,022$ & $+10,475$ \\
\hline \multicolumn{6}{|l|}{ Farmed Trees (1000s of Acres) } \\
\hline Base Case & 4 & $+1,208$ & $+2,176$ & +106 & $+1,557$ \\
\hline Endogenous Corn Prices & 4 & $+1,208$ & $+2,090$ & +104 & $+1,557$ \\
\hline \multicolumn{6}{|l|}{ Total (1000s of Acres) } \\
\hline Base Case & 3,121 & $+38,991$ & $+27,559$ & $+1,158$ & $+37,739$ \\
\hline Endogenous Corn Prices & 3,247 & $+38,865$ & $+28,947$ & $+3,135$ & $+38,113$ \\
\hline
\end{tabular}

Notes: For the RFS, LCFS, CAT and SUBS policies a "+ "indicates an increase in acreage relative to BAU. Land areas are measured in 1000s of acres. 
Table 7: Incentives for different innovation levels that reduce cellulosic ethanol costs under the LCFS and CAT.

\begin{tabular}{|c|c|c|c|c|c|c|c|c|c|}
\hline & \multicolumn{9}{|c|}{ LCFS } \\
\hline & $20 \%$ & $50 \%$ & $75 \%$ & $150 \%$ & $\mathbf{3 0 0 \%}$ & $500 \%$ & $1000 \%$ & $2000 \%$ & No Cell. \\
\hline$\Delta$ Social Surplus (\$ bn.) & $\$ 5.75$ & $\$ 13.09$ & $\$ 17.92$ & $\$ 26.28$ & $\$ 35.32$ & $\$ 38.77$ & $\$ 33.13$ & $\$ 10.24$ & $\$ 2.61$ \\
\hline$\Delta \mathrm{CS}$ & $\$ 2.97$ & $\$ 7.40$ & $\$ 10.95$ & $\$ 21.97$ & $\$ 34.63$ & $\$ 44.75$ & $\$ 57.10$ & $\$ 65.63$ & $\$ 67.08$ \\
\hline$\Delta \mathrm{PS}$ & $\$ 2.79$ & $\$ 5.69$ & $\$ 6.97$ & $\$ 4.31$ & $\$ 0.69$ & $-\$ 5.98$ & $-\$ 23.97$ & $-\$ 55.40$ & $-\$ 64.47$ \\
\hline$\Delta$ PS (Corn Ethanol) & $-\$ 0.40$ & $-\$ 1.11$ & $-\$ 1.98$ & $-\$ 5.81$ & $-\$ 12.50$ & $-\$ 21.26$ & $-\$ 41.96$ & $-\$ 75.43$ & $-\$ 85.03$ \\
\hline$\Delta$ PS (Cellulosic Ethanol) & $\$ 3.18$ & $\$ 6.80$ & $\$ 8.94$ & $\$ 10.11$ & $\$ 13.20$ & $\$ 15.28$ & $\$ 17.99$ & $\$ 20.03$ & $\$ 20.56$ \\
\hline \multicolumn{10}{|l|}{ Fuel Price (\$/gge) } \\
\hline Without Innovation & $\$ 2.98$ & $\$ 3.01$ & $\$ 3.04$ & $\$ 3.12$ & $\$ 3.22$ & $\$ 3.30$ & $\$ 3.40$ & $\$ 3.46$ & $\$ 3.48$ \\
\hline With Innovation & $\$ 2.96$ & $\$ 2.96$ & $\$ 2.96$ & $\$ 2.96$ & $\$ 2.96$ & $\$ 2.96$ & $\$ 2.96$ & $\$ 2.96$ & $\$ 2.96$ \\
\hline \multicolumn{10}{|l|}{ Average Abatement Cost $\left(\$ / \mathrm{MTCO}_{2} \mathrm{e}\right)$} \\
\hline Without Innovation & $\$ 78.52$ & $\$ 122.29$ & $\$ 151.51$ & $\$ 202.11$ & $\$ 256.76$ & $\$ 277.65$ & $\$ 243.53$ & $\$ 105.03$ & $\$ 58.87$ \\
\hline \multirow[t]{3}{*}{ With Innovation } & $\$ 48.58$ & $\$ 48.58$ & $\$ 48.58$ & $\$ 48.58$ & $\$ 48.58$ & $\$ 48.58$ & $\$ 48.58$ & $\$ 48.58$ & $\$ 48.58$ \\
\hline & \multicolumn{9}{|c|}{ CAT } \\
\hline & $20 \%$ & $\mathbf{5 0 \%}$ & $75 \%$ & $150 \%$ & $300 \%$ & $\mathbf{5 0 0 \%}$ & $1000 \%$ & $2000 \%$ & No Cell. \\
\hline$\Delta$ Social Surplus (\$ bn.) & $\$ 2.58$ & $\$ 4.16$ & $\$ 4.35$ & $\$ 4.38$ & $\$ 4.38$ & $\$ 4.38$ & $\$ 4.38$ & $\$ 4.38$ & $\$ 4.38$ \\
\hline$\Delta \mathrm{CS}$ & $\$ 16.71$ & $\$ 37.54$ & $\$ 42.44$ & $\$ 43.44$ & $\$ 43.44$ & $\$ 43.44$ & $\$ 43.44$ & $\$ 43.44$ & $\$ 43.44$ \\
\hline$\Delta \mathrm{PS}$ & $\$ 1.89$ & $\$ 3.05$ & $\$ 3.22$ & $\$ 3.24$ & $\$ 3.24$ & $\$ 3.24$ & $\$ 3.24$ & $\$ 3.24$ & $\$ 3.24$ \\
\hline$\Delta$ PS (Corn Ethanol) & $-\$ 0.03$ & $-\$ 0.06$ & $-\$ 0.06$ & $-\$ 0.07$ & $-\$ 0.07$ & $-\$ 0.07$ & $-\$ 0.07$ & $-\$ 0.07$ & $-\$ 0.07$ \\
\hline$\Delta$ PS (Cellulosic Ethanol) & $\$ 1.91$ & $\$ 3.11$ & $\$ 3.28$ & $\$ 3.31$ & $\$ 3.31$ & $\$ 3.31$ & $\$ 3.31$ & $\$ 3.31$ & $\$ 3.31$ \\
\hline$\Delta$ Carbon Mkt. Rev. or Sub. Payments ( $\$$ bn.) & $-\$ 16.02$ & $-\$ 36.43$ & $-\$ 41.31$ & $-\$ 42.30$ & $-\$ 42.30$ & $-\$ 42.30$ & $-\$ 42.30$ & $-\$ 42.30$ & $-\$ 42.30$ \\
\hline \multicolumn{10}{|l|}{ Fuel Price (\$/gge) } \\
\hline Without Innovation & $\$ 3.37$ & $\$ 3.53$ & $\$ 3.57$ & $\$ 3.58$ & $\$ 3.58$ & $\$ 3.58$ & $\$ 3.58$ & $\$ 3.58$ & $\$ 3.58$ \\
\hline With Innovation & $\$ 3.23$ & $\$ 3.23$ & $\$ 3.23$ & $\$ 3.23$ & $\$ 3.23$ & $\$ 3.23$ & $\$ 3.23$ & $\$ 3.23$ & $\$ 3.23$ \\
\hline \multicolumn{10}{|l|}{ Average Abatement Cost $\left(\$ / \mathrm{MTCO}_{2} \mathrm{e}\right)$} \\
\hline Without Innovation & $\$ 30.26$ & $\$ 39.21$ & $\$ 40.36$ & $\$ 40.54$ & $\$ 40.54$ & $\$ 40.54$ & $\$ 40.54$ & $\$ 40.54$ & $\$ 40.54$ \\
\hline \multirow[t]{3}{*}{ With Innovation } & $\$ 19.52$ & $\$ 19.52$ & $\$ 19.52$ & $\$ 19.52$ & $\$ 19.52$ & $\$ 19.52$ & $\$ 19.52$ & $\$ 19.52$ & $\$ 19.52$ \\
\hline & & & & & SUBS & & & & \\
\hline & $20 \%$ & $\mathbf{5 0 \%}$ & $75 \%$ & $150 \%$ & $300 \%$ & $500 \%$ & $1000 \%$ & $2000 \%$ & No Cell. \\
\hline$\Delta$ Social Surplus (\$ bn.) & $\$ 3.91$ & $\$ 2.84$ & $\$ 0.16$ & $-\$ 4.34$ & $-\$ 4.43$ & $-\$ 4.43$ & $-\$ 4.43$ & $-\$ 4.43$ & $-\$ 4.43$ \\
\hline$\Delta \mathrm{CS}$ & $\$ 0.00$ & $\$ 0.00$ & $\$ 0.00$ & $\$ 0.00$ & $\$ 0.00$ & $\$ 0.00$ & $\$ 0.00$ & $\$ 0.00$ & $\$ 0.00$ \\
\hline$\Delta \mathrm{PS}$ & $\$ 6.39$ & $\$ 13.12$ & $\$ 15.92$ & $\$ 17.29$ & $\$ 17.29$ & $\$ 17.29$ & $\$ 17.29$ & $\$ 17.29$ & $\$ 17.29$ \\
\hline$\Delta$ PS (Corn Ethanol) & $\$ 0.00$ & $\$ 0.00$ & $\$ 0.00$ & $\$ 0.00$ & $\$ 0.00$ & $\$ 0.00$ & $\$ 0.00$ & $\$ 0.00$ & $\$ 0.00$ \\
\hline$\Delta$ PS (Cellulosic Ethanol) & $\$ 6.39$ & $\$ 13.12$ & $\$ 15.92$ & $\$ 17.29$ & $\$ 17.29$ & $\$ 17.29$ & $\$ 17.29$ & $\$ 17.29$ & $\$ 17.29$ \\
\hline$\Delta$ Carbon Mkt. Rev. or Sub. Payments ( $\$$ bn.) & $\$ 2.48$ & $\$ 10.29$ & $\$ 15.76$ & $\$ 21.63$ & $\$ 21.72$ & $\$ 21.72$ & $\$ 21.72$ & $\$ 21.72$ & $\$ 21.72$ \\
\hline \multicolumn{10}{|l|}{ Fuel Price (\$/gge) } \\
\hline Without Innovation & $\$ 2.75$ & $\$ 2.75$ & $\$ 2.75$ & $\$ 2.75$ & $\$ 2.75$ & $\$ 2.75$ & $\$ 2.75$ & $\$ 2.75$ & $\$ 2.75$ \\
\hline With Innovation & $\$ 2.75$ & $\$ 2.75$ & $\$ 2.75$ & $\$ 2.75$ & $\$ 2.75$ & $\$ 2.75$ & $\$ 2.75$ & $\$ 2.75$ & $\$ 2.75$ \\
\hline \multicolumn{10}{|l|}{ Average Abatement Cost $\left(\$ / \mathrm{MTCO}_{2} \mathrm{e}\right)$} \\
\hline Without Innovation & $\$ 93.99$ & $\$ 123.30$ & $\$ 149.00$ & $\$ 193.34$ & $\$ 194.45$ & $\$ 194.45$ & $\$ 194.45$ & $\$ 194.45$ & $\$ 194.45$ \\
\hline With Innovation & $\$ 82.30$ & $\$ 82.30$ & $\$ 82.30$ & $\$ 82.30$ & $\$ 82.30$ & $\$ 82.30$ & $\$ 82.30$ & $\$ 82.30$ & $\$ 82.30$ \\
\hline
\end{tabular}

Notes: The change in surplus is the additional surplus from technology that reduces costs of cellulosic ethanol (With Innovation) to our base cost levels relative to counterfactuals where cellulosic ethanol costs are higher (Without Innovation). The columns show counterfactuals where cellulosic costs without innovation range from 20 percent to 2000 percent higher. The final column is the case where cellulosic ethanol is not developed. Surplus is calculated as PS + CS + Carbon Market Revenue - Subsidy Payments. 